\title{
Meta-Analysis of Gene Expression Changes in the Blood of Patients with Mild Cognitive Impairment and Alzheimer's Disease Dementia
}

\author{
Virginie Bottero and Judith A. Potashkin * \\ Center for Neurodegenerative Disease and Therapeutics, The Chicago Medical School, Rosalind Franklin \\ University of Medicine and Science, North Chicago, IL 60064, USA; virginie.bottero@rosalindfranklin.edu \\ * Correspondence: judy.potashkin@rosalindfranklin.edu; Tel.: +847-578-8677; Fax: +847-578-3268
}

Received: 25 September 2019; Accepted: 28 October 2019; Published: 30 October 2019

\begin{abstract}
Background: Dementia is a major public health concern affecting approximately 47 million people worldwide. Mild cognitive impairment (MCI) is one form of dementia that affects an individual's memory with or without affecting their daily life. Alzheimer's disease dementia (ADD) is a more severe form of dementia that usually affects elderly individuals. It remains unclear whether $\mathrm{MCI}$ is a distinct disorder from or an early stage of ADD. Methods: Gene expression data from blood were analyzed to identify potential biomarkers that may be useful for distinguishing between these two forms of dementia. Results: A meta-analysis revealed 91 genes dysregulated in individuals with MCI and 387 genes dysregulated in ADD. Pathway analysis identified seven pathways shared between $\mathrm{MCI}$ and ADD and nine ADD-specific pathways. Fifteen transcription factors were associated with $\mathrm{MCI}$ and ADD, whereas seven transcription factors were specific for ADD. Mir-335-5p was specific for ADD, suggesting that it may be useful as a biomarker. Diseases that are associated with MCI and ADD included developmental delays, cognition impairment, and movement disorders. Conclusion: These results provide a better molecular understanding of peripheral changes that occur in $\mathrm{MCI}$ and ADD patients and may be useful in the identification of diagnostic and prognostic biomarkers.
\end{abstract}

Keywords: mild cognitive impairment; Alzheimer's disease; dementia; gene expression; network analysis

\section{Introduction}

Dementia is a growing public health concern with rising prevalence rates estimated to increase to 131 million worldwide within the next three decades [1]. Cognitive decline is often seen in elderly individuals and in patients who are diagnosed with vascular dementia, Lewy body dementia, frontotemporal dementia, Huntington's disease, Creutzfeldt-Jakob disease, Parkinson's disease, and Alzheimer's disease dementia (ADD). The Alzheimer's Association estimates that ADD accounts for 60 to $80 \%$ of dementia cases and is the sixth-leading cause of death in the United States.

$\mathrm{ADD}$ is a progressive disease where dementia gradually worsens over a number of years. The diagnostic criteria for ADD have evolved as we have gained a better understanding of the disease. Before 1984, criteria were focused on the advanced stage of the disease and were based solely on cognitive decline. Since 2011, AD has been identified as a clinical-biological framework based on the National Institute on Aging-Alzheimer's Association (NIA-AA) criteria and now, the utilization of biomarkers for in vivo detection of $\mathrm{AD}$ pathophysiology has been recommended for clinical trials and medical practice [2]. The preclinical phase may start as early as 20 years before the appearance of symptoms. During this period, modifications in the brain such as amyloid buildup and cellular damages are observed. In early ADD stages, patients suffer from short-term memory 
loss but may also present with other cognitive impairment such as the ability to find words or make judgments. Mild cognitive impairment (MCI) patients are characterized by memory and/or other cognitive problems that are greater than normal for a person's age and education, but do not interfere with his or her independence. A MCI patient may or may not progress to ADD, but is at significantly increased risk for conversion. At the clinical stage, ADD patients present with cognitive impairment, memory loss, word-finding difficulties, and visual/spatial deficiencies that affect their quality of life and result in the need for assisted living and the inability to work. A recent study determined that the addition of a biological diagnostic to the clinical diagnostic is a more powerful method because it includes ADD asymptomatic patients [3].

The brains of ADD patients are characterized by the accumulation of amyloid-beta $(A \beta)$ plaques and hyperphosphorylated tau in the form of neurofibrillary tangles. Familial ADD patients develop early onset ADD and have mutations in the amyloid precursor protein (APP), presenilin 1 (PSEN1), and presenilin 2 (PSEN2) genes that regulate the production of the $\mathrm{A} \beta$ proteins. However, the vast majority of ADD cases present as late onset, usually after age 65, and are considered sporadic. Genetic and environmental factors play a role in the development of sporadic ADD. The epsilon 4 allele of apolipoprotein $\mathrm{E}(A P O E)$ is the greatest genetic factor identified so far that increases the risk of an individual for ADD, possibly accounting for $50 \%$ of sporadic ADD patients [4]. The effects of ApoE on cognition are mediated through the classic pathological hallmarks of ADD, A $\beta$, and Tau $[5,6]$. In addition to ApoE4, there are over 25 additional genetic risk modifiers for late onset ADD [7-9].

The identification of early markers of ADD is critical to diagnosis and therapy. Multiple phase III clinical trials were unsuccessful at treating ADD [10]. This has led to the recognition for the need to intervene at much earlier stages in the disease so as to prevent the cascade of multiple pathologic pathways associated with AD [11]. Imaging techniques and cerebrospinal (CSF) biomarkers have been developed in the last few decades to improve ADD diagnostics. During the preclinical stage of the disease, the National Institute on Aging (NIA) and the Alzheimer's Association favored the use of amyloid biomarkers [12]. It has been shown that A $\beta 42$ accumulation in the CSF or by PET amyloid imaging of the brain were one of the first abnormalities identified [13]. Whereas CSF and imaging biomarkers are proven to be very efficient, blood biomarkers potentially have important advantages because they would be minimally invasive and relatively inexpensive. Many neural pathologies including ADD are reflected in changes in gene expression, splicing, and protein profiles in brain and CSF, but also in blood, providing a precedent for searching this bodily fluid for biomarkers [14-18].

Microarray and high-throughput technologies for gene expression are essential tools for identifying differential patterns of gene expression that are characteristic of disease. Nonetheless, the interpretation of gene expression patterns can be difficult. Network analysis of gene expression data has identified disease-causing genes, protein biomarkers, and biological pathways associated with ADD [19]. Network analysis of eight genes associated with ADD identified 31 new candidate genes related to late-onset ADD [20]. Additional network analyses using gene expression data from postmortem ADD patients' brain tissue identified molecular networks that are relevant to ADD pathology [21-24]. Network analysis was also used to identify genes and miRNAs that correlate with different stages of the disease progression [25-27].

Integrative approaches combining multiple data sources have been widely used to identify susceptibility genes that are involved in ADD pathogenesis [28-30]. Meta-analysis of microarray datasets determined ADD-specific genes signatures that are specific to the brain [31-36]. In addition, the meta-analysis of expression data from the blood of ADD patients identified several miRNAs as promising biomarkers for ADD [37]. By comparing the brain transcriptome of ADD patients to that of patients with other neurodegenerative diseases, seven genes were identified that are ADD-specific [38]. By comparing ADD and Parkinson's disease transcriptomes, it has become clear that these two diseases share some dysregulated gene expressions patterns [39]. In addition, ADD and ischemic stroke share transcriptionally dysregulated genes [40]. Finally, systems biology approaches identified common pathophysiological mechanisms that are shared between ADD and type 2 diabetes [41,42]. 
While research on the progression of ADD thus far has been productive, a better understanding of the affected genes and pathways that are involved in the pathogenesis of ADD is needed before we can accurately and reliably detect the pre-clinical stages of the disease as well as predict risk. In the present study, we performed transcriptomic and network analyses of gene expression datasets from $\mathrm{MCI}$ as well as early and late ADD patients to better understand the shared molecular pathways that are dysregulated in both forms of dementia and to shed more light on how ADD progresses.

\section{Results}

\section{1. $M C I$ and $A D D$ Gene Expression Meta-Analysis}

We first identified common genes that are dysregulated in MCI and ADD (Table 1). The overall analysis strategy is presented in Figure 1. The two microarray datasets that were obtained from the BaseSpace Correlation Engine (BSCE) from blood tissue of MCI patients were analyzed by Venn diagram (Figure 2a,b, Tables S1 and S2) and UpSetR analysis (Figure S1). From this, 91 differentially expressed genes were identified in MCI. Similarly, the analysis of the four microarray datasets from blood tissue of ADD patients identified 387 genes that were shared in at least 2 out of the 4 arrays (Figure 2c,d and Figure S1, Table S2). Out of the 387 ADD genes, 10 of them were shared in 3 arrays (AIF1, C9orf78, CMTM2, GNG11, PPBP , PPP2R5C, RGS10, HELZ2, SNTB2, RNA28S5) and only SYF2 was shared in all 4 studies. Finally, it is interesting to note that 85 of the MCI genes are also dysregulated in ADD (Table S3).

\section{Gene expression arrays}

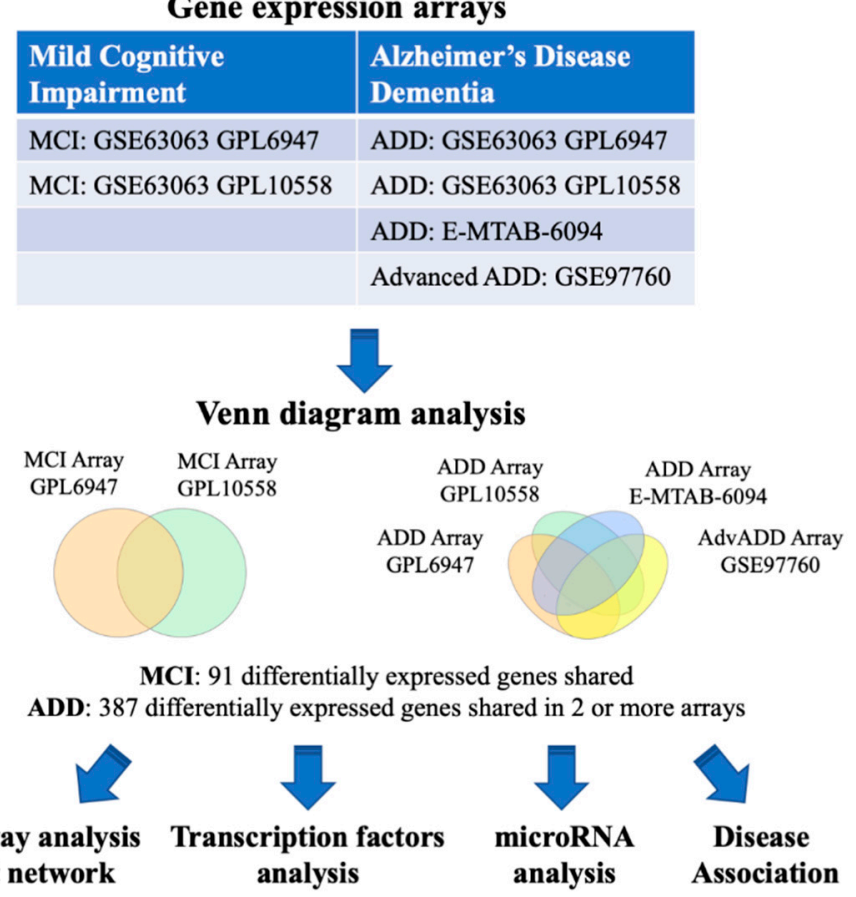

Figure 1. Flowchart of the study. The BaseSpace Correlation Engine (BSCE) was searched and blood gene expression studies with data from mild cognitive impairment (MCI) and Alzheimer's disease dementia (ADD) were included in this study. Venn diagram analysis was used to identify shared dysregulated genes. The MCI and ADD dysregulated genes were analyzed for shared functional pathways, transcription factors, and miRNAs regulation as well as disease associations. The arrows represent the flow of the steps in the study. 
Table 1. Gene expression datasets used in this study.

\begin{tabular}{cccccc}
\hline Disease & Datasets & Platform & Cases & Controls & References \\
\hline MCI & $\begin{array}{c}\text { GSE63063 } \\
(\text { GSE63060, GSE63061) }\end{array}$ & $\begin{array}{c}\text { Illumina } \\
\text { GPL6947 }\end{array}$ & 80 & 104 & [43-45] \\
\hline MCI & $\begin{array}{c}\text { GSE63063 } \\
(\text { GSE63060, GSE63061) }\end{array}$ & $\begin{array}{c}\text { Illumina } \\
\text { GPL10558 }\end{array}$ & 109 & 136 & {$[43-45]$} \\
\hline ADD & $\begin{array}{c}\text { GSE63063 } \\
(\text { GSE63060, GSE63061) }\end{array}$ & $\begin{array}{c}\text { Illumina } \\
\text { GPL6947 }\end{array}$ & 142 & 104 & [43-45] \\
\hline ADD & $\begin{array}{c}\text { GSE63063 } \\
\text { (GSE63060, GSE63061) }\end{array}$ & $\begin{array}{c}\text { Illumina } \\
\text { GPL10558 }\end{array}$ & 139 & 136 & [43-45] \\
\hline ADD & E-MTAB-6094 & $\begin{array}{c}\text { Agilent } \\
\text { G4845A }\end{array}$ & 22 & 13 & Not published \\
\hline AdvADD & GSE97760 & $\begin{array}{c}\text { Agilent } \\
\text { GPL16699 }\end{array}$ & 9 & 10 & {$[46]$} \\
\hline
\end{tabular}

Blood transcriptomics studies selected for the analysis. ${ }^{*}$ GSE63063 dataset are composed of two studies: GSE63060 and GSE63061. MCI: Mild cognitive impairment, ADD: Alzheimer's disease dementia, AdvADD: Advanced Alzheimer's disease dementia.

(a)

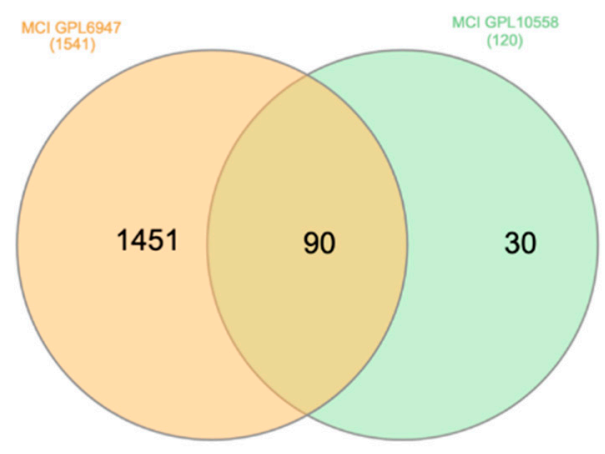

(b)

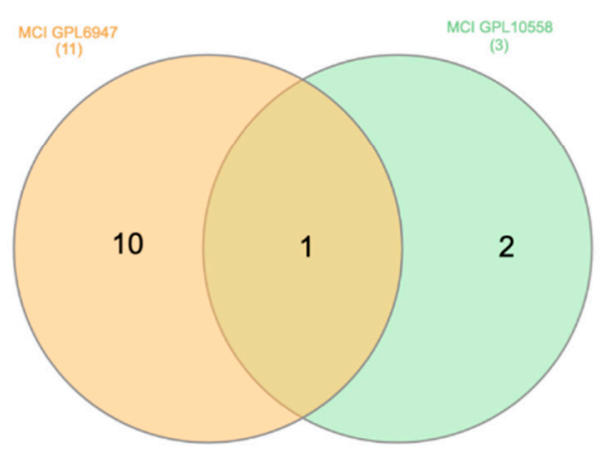

(c)

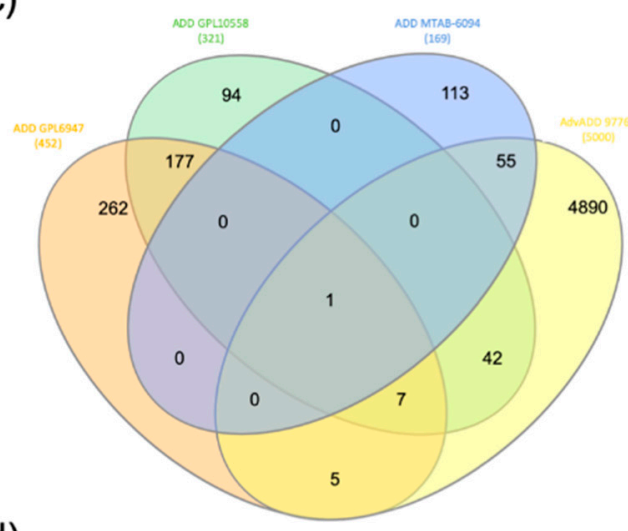

(d)

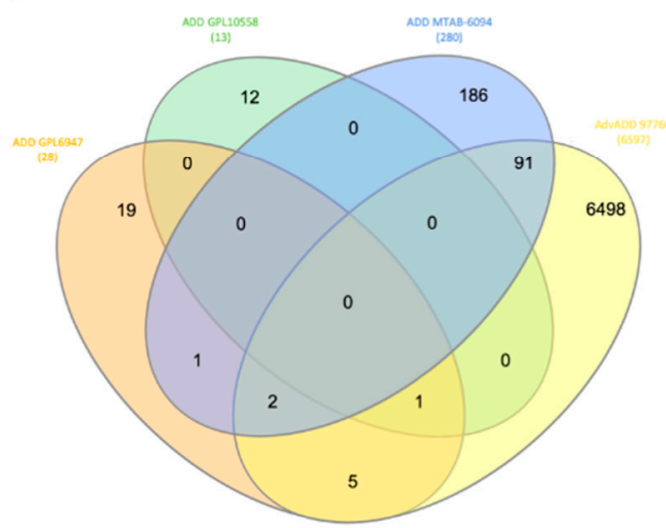

Figure 2. Venn diagram analysis of the genes down and up regulated in MCI and ADD. (a,b) The genes downregulated (a) and upregulated (b) in the MCI arrays (GSE63063, GPL10558, and GPL6947 platforms) were downloaded from BSCE and analyzed by Venn diagrams using the following website http://www.interactivenn.net/. (c,d) The genes downregulated (c) and upregulated (d) in the ADD arrays (GSE63063 GPL10558 and GPL6947 platforms, MTAB-6094, and GSE97760) were downloaded from BSCE and analyzed by Venn diagrams. 


\subsection{Pathway Enrichment Analysis}

The MCI and ADD dysregulated genes were uploaded to NetworkAnalyst to perform a pathway enrichment network analysis using the Kyoto Encyclopedia of Genes and Genome (KEGG) database (Figure 3). The MCI analysis identified 10 pathways: ribosome, oxidative phosphorylation, Parkinson's disease, Alzheimer's disease, Huntington's disease, non-alcoholic fatty liver disease, cardiac muscle contraction, retrograde endocannabinoid signaling, and protein export and metabolic pathways. The ADD analysis revealed 15 pathways. Seven pathways were common with MCI analysis (ribosome, oxidative phosphorylation, Parkinson's disease, Alzheimer's disease, Huntington's disease, non-alcoholic fatty liver disease, and cardiac muscle contraction). Nine pathways were ADD-specific (proteasome, collecting duct acid secretion, spliceosome, Helicobacter pylori infection, nucleotide excision repair, hepatitis C infection, Vibrio cholerae infection, Kaposi's sarcoma-associated herpesvirus (KSHV) infection, and Epstein-Barr virus (EBV) infection). The list of genes corresponding to each of these pathways is presented in Table S4.

(a)

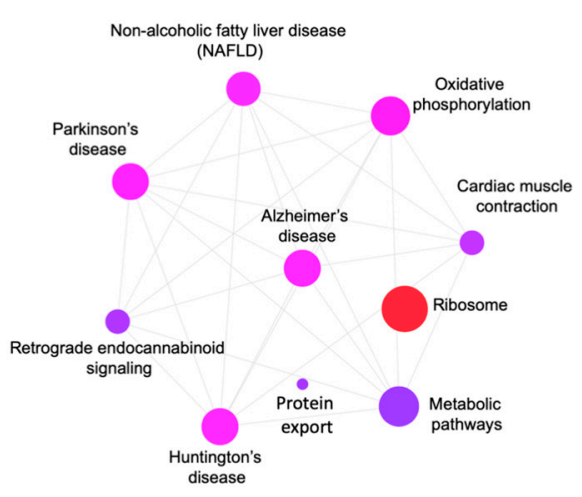

(c)

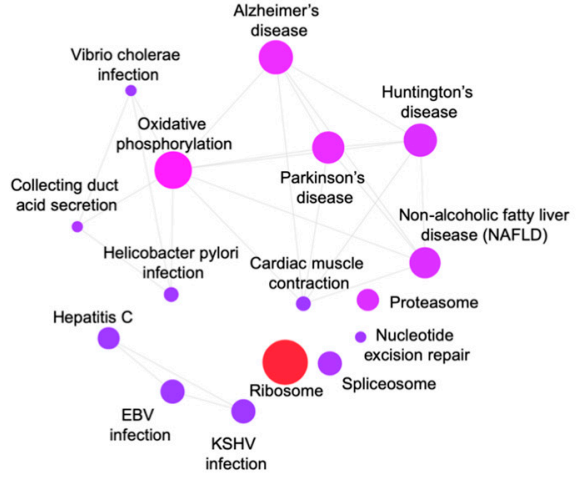

(b)

\begin{tabular}{|l|c|c|}
\hline PATHWAY & HITS & P.VALUE \\
\hline Ribosome & $23 / 153$ & $7.67 \times 10^{-26}$ \\
\hline Oxidative phosphorylation & $14 / 133$ & $1.78 \times 10^{-13}$ \\
\hline Parkinson's disease & $12 / 142$ & $1.62 \times 10^{-10}$ \\
\hline Alzheimer's disease & $12 / 171$ & $1.41 \times 10^{-9}$ \\
\hline $\begin{array}{l}\text { Huntington's disease } \\
\text { Non-alcoholic fatty liver disease } \\
\text { (NAFLD) }\end{array}$ & $12 / 193$ & $5.66 \times 10^{-9}$ \\
\hline $\begin{array}{l}\text { Cardiac muscle contraction } \\
\text { Retrograde endocannabinoid } \\
\text { signaling }\end{array}$ & $5 / 78$ & $6.01 \times 10^{-8}$ \\
\hline Protein export & $1.97 \times 10^{-4}$ \\
\hline Metabolic pathways & $15 / 143$ & $3.56 \times 10^{-3}$ \\
\hline
\end{tabular}

(d)

\begin{tabular}{|l|c|c|}
\hline PATHWAY & HITS & P.VALUE \\
\hline Ribosome & $34 / 153$ & $1.49 \times 10^{-24}$ \\
\hline Oxidative phosphorylation & $21 / 133$ & $2.42 \times 10^{-12}$ \\
\hline Alzheimer's disease & $17 / 171$ & $4.01 \times 10^{-7}$ \\
\hline Parkinson's disease & $15 / 142$ & $9.18 \times 10^{-7}$ \\
\hline Proteasome & $8 / 45$ & $7.59 \times 10^{-6}$ \\
\hline $\begin{array}{l}\text { Non-alcoholic fatty liver } \\
\text { disease (NAFLD) }\end{array}$ & $14 / 149$ & $8.6 \times 10^{-6}$ \\
\hline Huntington's disease & $16 / 193$ & $9.74 \times 10^{-6}$ \\
\hline Collecting duct acid secretion & $4 / 27$ & $3.27 \times 10^{-3}$ \\
\hline Spliceosome & $9 / 134$ & $3.94 \times 10^{-3}$ \\
\hline Helicobacter Pylori infection & $5 / 68$ & $2.06 \times 10^{-2}$ \\
\hline Nucleotide excision repair & $4 / 47$ & $2.32 \times 10^{-2}$ \\
\hline Hepatitis C infection & $8 / 155$ & $2.79 \times 10^{-2}$ \\
\hline Vibrio cholerae infection & $4 / 50$ & $2.84 \times 10^{-2}$ \\
\hline KSHV infection & $9 / 186$ & $2.93 \times 10^{-2}$ \\
\hline Cardiac muscle contraction & $5 / 78$ & $3.48 \times 10^{-2}$ \\
\hline EBV infection & $9 / 201$ & $4.47 \times 10^{-2}$ \\
\hline
\end{tabular}

Figure 3. Pathway analysis. The genes that were commonly dysregulated in the MCI arrays (a,b) and in at least two of the ADD arrays $(\mathbf{c}, \mathbf{d})$ were obtained from the Venn diagram analysis. The genes lists were uploaded to https://www.networkanalyst.ca/NetworkAnalyst/faces/home.xhtml where an enrichment network analysis was performed using the Kyoto Encyclopedia of Genes and Genome (KEGG) database.

\subsection{Gene-Transcription Factors Interaction Analysis}

In order to identify key regulators of the $\mathrm{MCI}$ and $\mathrm{ADD}$ dysregulated genes, a transcription factor analysis was performed. The gene transcription factor interactomes were performed on NetworkAnalyst using three different databases (ENCODE, ChEA, and JASPAR). The transcription factors that were shared by all the databases were identified by Venn diagram analysis (Figure $4 a, b$ ). In the MCI analysis, 15 transcription factors (Figure 4a,c) and in the ADD analysis, 22 transcription factors, respectively, were shared by all the databases (Figure $4 b, d$ ). Interestingly, all the transcription 
factors regulating the MCI genes are shared with ADD (ELK, STAT1, PPARG, YY1, EGR1, E2F4, CEBPB, GATA3, JUN, RELA, GATA2, SREBF1, CREB1, RUNX1, STAT3). Seven transcription factors were specific to the ADD genes (ARNT, GATA1, KFL4, SREBF2, SRF, MYB, MEF2A).

(a)

(b)
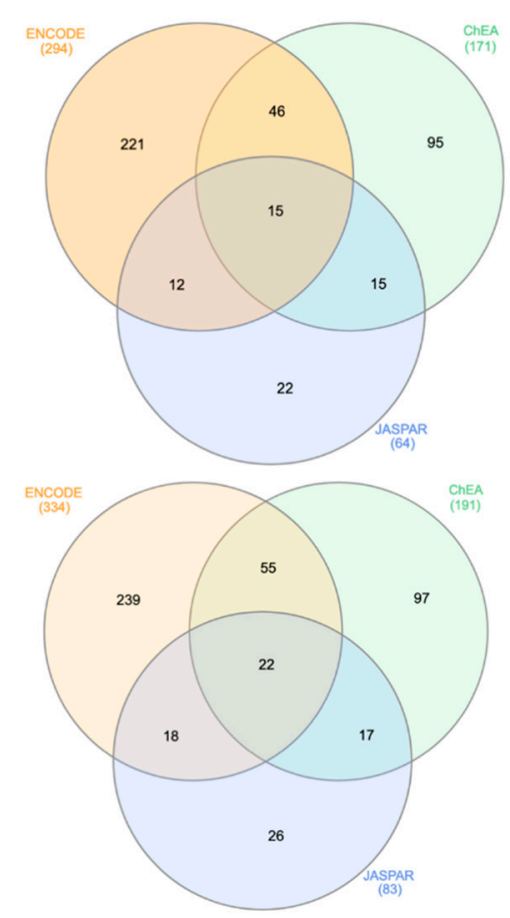

(c)

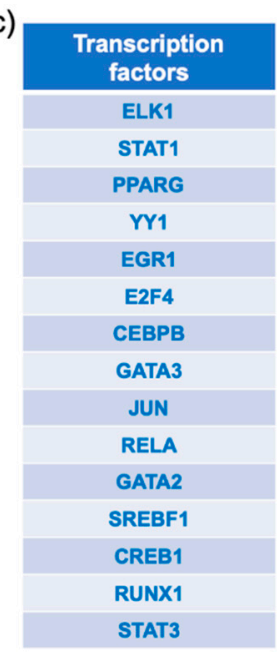

(d)

\begin{tabular}{|c|}
\hline $\begin{array}{c}\text { Transcription } \\
\text { factors }\end{array}$ \\
\hline ELK1 \\
\hline ARNT \\
\hline GATA2 \\
\hline PPARG \\
\hline STAT1 \\
\hline EGR1 \\
\hline GATA1 \\
\hline KFL4 \\
\hline Yr1 \\
\hline E2F4 \\
\hline SREBF2 \\
\hline CREB1 \\
\hline GATA3 \\
\hline RELA \\
\hline CEBPB \\
\hline RUNX1 \\
\hline SREBF1 \\
\hline STAT3 \\
\hline JUN \\
\hline SRF \\
\hline MYB \\
\hline MEF2A \\
\hline
\end{tabular}

Figure 4. Transcription factors analysis. The genes commonly dysregulated in the MCI arrays and in at least two out of the ADD arrays were obtained using Venn diagram analysis. The gene lists were uploaded to https://www.networkanalyst.ca/NetworkAnalyst/faces/home.xhtml. The gene-transcription factor interaction network was performed with ENCODE, ChEA, and JASPAR. A Venn diagram analysis was performed to identify the transcription factors identified by the three methods. (a,b) represent the results of the Venn diagram analysis performed with MCI and ADD genes, respectively. The transcription factors interacting with the MCI and ADD genes were listed in $(\mathbf{c}, \mathbf{d})$, respectively. Transcription factors in blue are common in MCI and ADD analysis whereas the transcription factors in red were specific to ADD regulation.

\subsection{Gene-miRNA Interaction Analysis}

To further understand the regulation of MCI and ADD genes, a gene-miRNA interaction network analysis was performed in NetworkAnalyst. Comprehensive experimentally validated miRNA-gene interaction data was collected from TarBase and miRTarBase. The MCI genes resulted in the identification of three subnetworks. The first subnetwork had 58 genes as seeds and resulted in 686 miRNAs. The second subnetwork was centered on $U Q C R H$, which can be regulated by 16 miRNAs. Finally, the third subnetwork was centered on $C O X 7 A 2$, which can be regulated by 2 miRNAs. Altogether, 704 miRNAs were identified as regulators of the MCI genes. These miRNAs were ranked by decreasing degree followed by decreasing betweenness. The top MCI miRNAs, with a degree superior or equal to 5, were listed in Table 2. The ADD genes network identified 1773 miRNAs that were ranked based on their degrees and betweenness. The top miRNAs (degree superior or equal to 20) are listed in Table 2. A Venn diagram analysis was performed to determine the shared miRNAs that are involved in MCI and ADD regulation and 683 miRNAs were identified. Among the highly ranked miRNAs listed in Table 2, all the miRNAs that may regulate the MCI genes are shared with the ADD genes, except Hsa-mir-335-5p, which is unique to the ADD genes and may regulate genes that are involved in late stages of ADD. 
Table 2. MicroRNA analysis.

\begin{tabular}{|c|c|c|c|}
\hline Gene & miRNA & Degree & Betweenness \\
\hline \multirow{17}{*}{$\mathrm{MCI}$} & hsa-mir-16-5p & 15 & 29305 \\
\hline & hsa-mir-92a-3p & 11 & 13618 \\
\hline & hsa-mir-26b-5p & 10 & 16008 \\
\hline & hsa-mir-106b-5p & 7 & 8335 \\
\hline & hsa-mir-93-5p & 7 & 7370 \\
\hline & hsa-mir-20a-5p & 7 & 7297 \\
\hline & hsa-mir-320a & 7 & 3580 \\
\hline & hsa-let-7a-5p & 6 & 11229 \\
\hline & hsa-mir-484 & 6 & 3618 \\
\hline & hsa-mir-615-3p & 6 & 3342 \\
\hline & hsa-mir-18a-3p & 5 & 8997 \\
\hline & hsa-mir-7977 & 5 & 6593 \\
\hline & hsa-mir-17-5p & 5 & 4484 \\
\hline & hsa-mir-155-5p & 5 & 4269 \\
\hline & hsa-mir-193b-3p & 5 & 3279 \\
\hline & hsa-mir-450a-1-3p & 5 & 3266 \\
\hline & hsa-mir-887-5p & 5 & 1840 \\
\hline \multirow{18}{*}{ ADD } & hsa-mir-16-5p & 51 & 101307 \\
\hline & hsa-mir-26b-5p & 48 & 69947 \\
\hline & hsa-mir-92a-3p & 33 & 53149 \\
\hline & hsa-mir-193b-3p & 30 & 65562 \\
\hline & hsa-mir-17-5p & 28 & 45790 \\
\hline & hsa-mir-93-5p & 28 & 32553 \\
\hline & hsa-mir-106b-5p & 28 & 32245 \\
\hline & hsa-mir-20a-5p & 26 & 27726 \\
\hline & hsa-mir-192-5p & 26 & 22623 \\
\hline & hsa-mir-335-5p & 25 & 40587 \\
\hline & hsa-mir-186-5p & 24 & 40049 \\
\hline & hsa-mir-615-3p & 24 & 26450 \\
\hline & hsa-let-7b-5p & 23 & 44950 \\
\hline & hsa-mir-155-5p & 23 & 33976 \\
\hline & hsa-mir-215-5p & 23 & 16736 \\
\hline & hsa-mir-20b-5p & 21 & 16266 \\
\hline & hsa-mir-519d-3p & 21 & 16266 \\
\hline & hsa-let-7a-5p & 20 & 22235 \\
\hline
\end{tabular}

The genes that are commonly dysregulated in the MCI arrays and in at least two of the ADD arrays were obtained using Venn diagram analysis. The genes lists were uploaded to https://www.networkanalyst.ca/NetworkAnalyst/ faces/home.xhtml. The gene-microRNA interactome was created using TarBase and miRTarBase databases. The microRNAs with a degree $\geq 5$ that may regulate the MCI genes are listed, the microRNAs with a degree $\geq 20$ that may regulate the ADD genes are listed. In green is the microRNA that was only identified in late ADD. 


\subsection{Gene-Disease Association Analysis}

A gene-disease association network analysis was performed in NetworkAnalyst. The MCI genes resulted in the identification of three subnetworks. Altogether, 119 associated diseases were identified with the MCI genes. These associated diseases were ranked by decreasing degree followed by decreasing betweenness. The top MCI associated diseases, with a degree superior or equal to 3 , are listed in Table 3. The ADD genes network identified 631 associated diseases that were ranked based on their degrees and betweenness. The top associated diseases (degree superior or equal to 6) are listed in Table 3. The full list of diseases that are associated with MCI and ADD are listed in Table S5. Interestingly, most of the diseases that are associated with the MCI and ADD genes are connected to developmental delay, cognition impairment, and movement disorders. A Venn diagram analysis was performed to determine the shared associated diseases between MCI and ADD. All the associated diseases that were unveiled with MCI genes were also associated with the ADD genes (Table S5).

Table 3. Disease association analysis.

\begin{tabular}{|c|c|c|c|}
\hline Gene & Disease Associated & Degree & Betweenness \\
\hline \multirow{14}{*}{$\mathrm{MCI}$} & Autosomal recessive predisposition & 5 & 1795 \\
\hline & Failure to gain weight & 3 & 306 \\
\hline & Pediatric failure to thrive & 3 & 306 \\
\hline & Muscle degeneration & 3 & 296 \\
\hline & Neurogenic muscular atrophy & 3 & 296 \\
\hline & Skeletal muscle atrophy & 3 & 296 \\
\hline & $\begin{array}{l}\text { Neurogenic muscle atrophy, especially in } \\
\text { the lower limbs }\end{array}$ & 3 & 296 \\
\hline & Cerebellar ataxia & 3 & 161 \\
\hline & Muscle hypotonia & 3 & 161 \\
\hline & Hyperreflexia & 3 & 161 \\
\hline & Global developmental delay & 3 & 161 \\
\hline & Cognitive delay & 3 & 161 \\
\hline & Mental and motor retardation & 3 & 161 \\
\hline & Hypertrophic cardiomyopathy & 3 & 123 \\
\hline \multirow{8}{*}{$\mathrm{ADD}$} & Autosomal recessive predisposition & 11 & 25695 \\
\hline & Liver cirrhosis experimental & 9 & 7088 \\
\hline & Schizophrenia & 8 & 11805 \\
\hline & Strabismus & 7 & 16263 \\
\hline & Failure to gain weight & 6 & 6147 \\
\hline & Pediatric failure to thrive & 6 & 6147 \\
\hline & Hyperreflexia & 6 & 4072 \\
\hline & Muscle hypotonia & 6 & 3821 \\
\hline
\end{tabular}

The genes that are commonly dysregulated in the MCI arrays and in at least two of the ADD arrays were obtained using Venn diagram analysis. The genes lists were uploaded to https://www.networkanalyst.ca/NetworkAnalyst/ faces/home.xhtml. The gene-disease association networks were created using DisGeNet databases. The associated diseases with a degree $\geq 3$ that may regulate the MCI genes are listed, whereas the associated diseases with a degree $\geq 6$ that may regulate the ADD gene are listed. 


\section{Discussion}

\subsection{MCI and ADD Dysregulated Genes}

ADD has a long preclinical phase where the disease may start as early as 20 years before the appearance of symptoms. During the preclinical phase in ADD, mild cognitive impairment is common. By meta-analysis of MCI and ADD gene expression arrays studies, we identified dysregulated peripheral pathways in the blood of MCI and ADD patients that are potentially useful for identifying biomarkers.

The transcriptomic analysis of two MCI studies identified 91 dysregulated genes. Several of them have previously been linked to ADD. The levels of diazepam-binding inhibitor (DBI) were downregulated in both blood arrays. The levels of DBI in the cerebrospinal fluids were elevated in parkinsonian subjects with dementia and in patients with ADD [47]. DBI was decreased in ADD hippocampal protein extracts, whereas RNA sequencing of the parietal cortex of ADD patients suggested an upregulation of $D B I[48,49]$. The dysregulated MCI genes included those coding for the NADH: Ubiquinone Oxidoreductase subunits (NDUFA1, NDUFB2, NDUFA4, NDUFB3, and NDUFB3), all of which were downregulated in the MCI arrays. Interestingly, NDUFA1 and NDUFB2 were identified as central genes in a functional motif network using hippocampal and cell model transcriptomic data [50]. NDUFB3 was decreased in the brain proteome of late onset ADD patients [51] and its gene expression was decreased in the entorhinal cortex of ADD patients stages V to VI [52]. In addition, NDUFA4 was also down-regulated in the brain proteome of early onset ADD individuals [51].

Of interest, 37 ribosomal subunit genes were downregulated in MCI. Earlier studies showed that several ribosomal subunits are reduced in ADD. RPL26 staining was reduced in neurons of layer II of the entorhinal cortex in ADD patients [53]. RPL35A was reduced in the retina of aged APP/PS1 (ADD-like) mice [54]. By comparing blood and brain transcriptomes in a systematic analysis, an RNA signature comprising NDUFA1, MRPL51, and RPL36AL discriminated between ADD patients and controls with high sensitivity and specificity [55]. A prominent gene in the regulation of inflammation, S100A8, is downregulated in the MCI blood arrays that were analyzed. According to the gene expression results, S100A8 protein levels were decreased in the serum of ADD patients [56]. Interestingly, S100A8 also delays $A \beta$ aggregation, suggesting a regulatory function [57]. Finally, the levels of thioredoxin-1 $(T X N)$, an anti-oxidant, were reduced in the blood of MCI patients in the RNA arrays that were analyzed. In accordance with this result, a decrease in the protein level of TXN was also observed in the hippocampus and cerebellum of amnesic MCI patients [58]. TXN protein is decreased in the amygdala, superior and middle temporal gyri, and hippocampus/parahippocampal gyrus of ADD patients [59]. In addition, altered cellular localization or oxidized forms of TXN may affect its function in ADD patients $[60,61]$.

The blood transcriptomic meta-analysis of ADD patients identified SYF2 as the only mRNA that was downregulated in all four studies. This pre-mRNA splicing factor is involved in cell cycle progression and may be involved in neuroinflammation [62]. The transcriptional level of the regulator of G-protein signaling 10 (RGS10) was downregulated in three out of the four studies that were analyzed. It has been proposed that RGS10 may have a protective role in neuronal neuroinflammation [63]. The mRNA levels of the platelet basic protein PPBP were downregulated in two studies. Interestingly, a downregulation of PPBP protein levels was also detected in the serums of ADD patients compared with healthy controls [56].

\subsection{MCI and ADD Enrichment Pathways}

Network and pathway analysis revealed that all the pathways that were identified from the analysis of the MCI genes are shared with ADD, strongly suggesting that MCI often progresses to ADD. The most highly ranked pathway was the ribosomal pathway. Similar to this finding, the ribosomal pathway was also enriched in a network analysis that was performed using other datasets (GSE4226 and GSE4229) [64]. The ribosomal pathway was also significantly enriched in the differentially expressed genes from the neuronal dataset GSE4757 [65]. In addition, it has been shown that the transcriptional 
level of several ribosomal proteins genes were altered in the hippocampus of ADD patients and an impairment in protein synthesis was observed in the hippocampus and the superior middle temporal gyrus of MCI and ADD patients [66,67]. Finally, pathogenic Tau interacts closely with ribosomes in ADD, resulting in a reduction of protein synthesis, affecting synapses, and eventually leading to cognitive impairment [68].

The oxidative phosphorylation pathway was the second most highly ranked dysregulated pathway in both MCI and ADD. Recently, this pathway was enriched in ApoE4 hippocampal proteomic analysis [69]. Mitochondrial dysfunction and oxidative damage have been shown to have a crucial role in the pathogenesis of ADD [70]. It has been proposed that mitochondrial dysfunction is present in MCI patients and eventually leads to ADD [71,72].

Another pathway that is shared between MCI and ADD is the non-alcoholic fatty liver disease pathway (NAFLD). Interestingly, NAFLD was also enriched in a proteomic study from hippocampal extracts from APP/PS1 mice [69]. It has been shown that the liver contributes to the clearance of circulating $A \beta$ in the periphery [73]. Clinical studies have demonstrated an association between NAFLD and cognitive impairment in adults [74]. In addition, it has been shown that the content of $n-3$ polyunsaturated fatty acids in the liver strongly correlates with the cognitive status in patients with ADD [75]. The levels of docosahexaenoic acid, a neuroprotective fatty acid, are reduced in the brain and liver of ADD patients and correlate with cognitive impairment [75].

The cardiac muscle contraction pathway was also shared between MCI and ADD. An association between ADD and cardiovascular diseases has been observed. Several genes mutated in ADD have been implicated in heart dysfunction. For example, mutation in presenilin 1 (PSEN1) and presenilin 2 (PSEN2) are associated with cardiomyopathies [76]. Interestingly, in an ADD mouse model containing APP and PSEN1 mutations, cardiomyocytes presented with mechanical dysfunction [77]. The cognitive function of ADD patients with cerebrovascular atherosclerosis declined faster compared to ADD patients without cerebrovascular atherosclerosis [78].

Interestingly, some dysregulated pathways were specific to ADD patients. The role of the proteasome system in the development of ADD has been highly documented (reviewed in [79]). A two-way relationship between $A \beta$ and the proteasome has been observed. Proteasome activity decreases in brain areas that are affected by ADD [80]. This decrease of proteasome activity seems to be dependent on A $\beta$ accumulation [81-83]. In addition, it has been proposed that the proteasome system degrades $A \beta$ and decreases its toxicity, indicating that a decrease of proteasome activity might consequently be responsible for an increase of $A \beta$ [84]. Our meta-analysis indicates that proteasome activity might also be reduced due to a decrease in the transcriptional level of different proteasomal subunits genes.

A second affected pathway that is specific to ADD compared to MCI patients is the spliceosome. The re-localization and aggregation of the spliceosome protein U1 snRNP, a small nuclear ribonucleoprotein, has been observed in ADD pathology [85-88]. The accumulation of U1 snRNP resulted in changes in RNA splicing [89,90]. Aberrant splicing in presenilin 2 is present in sporadic ADD patients [91]. Furthermore, altered splicing of the receptor for advanced glycation end products (RAGE) occurs in ADD [92]. In our analysis, we observed that the genes that are involved in the spliceosome were downregulated in ADD. This result is in accordance with a proteomic study in which a downregulation of hnRNP-related proteins was observed after A $\beta$ peptide incubation on neuroblastoma cells [93]. More recently, a pathway enrichment analysis of the hippocampal proteome from ApoE4 mice compared to that of wild type highlighted the importance of the spliceosome in ADD [69].

Viral and bacterial infection pathways are also dysregulated in ADD. Several studies indicated a link between viral infection, the development of cognitive impairment, and ADD [94-98]. In addition, H. pylori infection has been associated with a reduction of cognition and ADD [99-101]. Furthermore, H. pylori-specific IgG antibody levels are significantly increased in blood and CSF of ADD patients [102]. At the molecular level, it has been shown that H. pylori infections induced an increase of tau phosphorylation [103]. 
Finally, the nucleotide excision repair pathways were identified as being dysregulated in ADD. The DNA damage that is caused by oxidative stress is usually repaired by nucleotide excision repair, a mechanism in which a damaged region of DNA is cut out and replaced by DNA synthesized using the undamaged strand as a template. The presence of oxidative stress in ADD is well established and most likely induces DNA damage [104]. The expression of several nucleotide excision repair components was altered in blood and postmortem brain tissue in MCI and ADD patients [105]. It has been shown that blood mRNA levels of 8-Oxoguanine DNA Glycosylase (OGG1), an enzyme that is responsible for the excision of mutated 8-Oxoguanine, was low in MCI and ADD. In addition, the blood mRNA level of Poly(ADP-Ribose) Polymerase 1 (PARP1), an enzyme that is involved in DNA repair enzyme by inducing the poly-ADP-ribosylation of proteins, was high in MCI and ADD. In the dataset that was analyzed, we observed a decreased expression of nucleotide excision repair genes in MCI and ADD, whereas advanced ADD datasets indicated increased expression, suggesting that these genes might be involved in early ADD events.

Altogether, this study suggests the existence of shared molecular pathways between MCI, ADD, Parkinson's disease, and Huntington's disease. In addition, the importance of mitochondrial function, ribosome, proteasome, and inflammation were revealed. Further research is expected to determine the roles of additional pathways including non-alcoholic fatty liver disease and nucleotide excision repair.

\subsection{Transcription Factors that May Regulate MCI and ADD Genes Expression in Blood}

We performed a gene-transcription factor interactome network to identify the transcription factors that may regulate the genes in blood in MCI and ADD. Fifteen transcription factors were enriched in MCI and ADD including ELK, STAT1, PPARG, YY1, EGR1, E2F4, CEBPB, GATA3, JUN, RELA, GATA2, SREBF1, CREB1, RUNX1, and STAT3. In accordance with our study, a network analysis from the array GSE4757 identified several transcription factors implicated in the pathogenesis of ADD [65]. Indeed, similar to our result, GATA2, YY1, PPARPG, and JUN were among the key regulatory molecules associated with transcriptional changes for ADD. More recently, the analysis of two other ADD microarray datasets (GSE4226 and GSE4229) also proposed a role for GATA2, PPARG, and YY1 as transcriptional regulators [64]. Yin Yang 1 (YY1) is implicated in neurodegenerative diseases [106-108]. This transcription factor is dysregulated in ADD brains and may play a role in the regulation of BACE1 and APP expression [109-112]. The analysis of hippocampal gene expression in ADD patients showed the deregulation of STAT3 and CEBPB [113].

In our analysis, seven transcription factors were specific to ADD including ARNT, GATA1, KFL4, SREBF2, SRF, MYB, and MEF2A. GATA-1 may regulate APP gene expression, whereas the transcription factor SREBF2 may be involved in the regulation of BACE1 expression [114,115]. In addition, APP/PS1 mice overexpressing SREBP-2 exhibit combined $A \beta$ accumulation and tau pathology [116]. Interestingly, it has been suggested that the expression levels of SREBP-2 could influence the survival rate of late onset ADD patients [117]. The transcription factor SRF was identified as a key regulator in ADD pathology [65]. The transcription factors MYB and MEF2A were respectively involved in protection for $A \beta$ toxicity and in neuronal survival $[118,119]$.

\section{4. miRNAs that May Regulate MCI and ADD Gene Expression in Blood}

To identify the microRNAs that may regulate the MCI and ADD genes, we performed a gene-microRNA interactome network. We ranked the microRNA based on the degree and betweenness in these networks. Whereas the analysis identified numerous potential microRNAs, we focused on the top ranked MCI and ADD microRNAs. All the microRNAs that were identified as potentially regulating $\mathrm{MCI}$ genes were also identified for ADD genes, confirming the close relationship between the two diseases and suggesting that they might be involved in early development of the pathology. Previous studies suggest that several of these miRNAs play a role in dementia and neurodegeneration. A meta-analysis study showed that mir-16-5p may regulate gene expression in ADD [64]. Mir-16-5p is differentially expressed in the CSF-derived exosomes of early onset ADD patients and in the 
brains of late onset ADD patients $[120,121]$. The upregulation of mir-92a-3p was observed in the plasma of both MCI and ADD subjects [122]. Mir-26b-5p expression is altered by $A \beta_{1-42}$ [123]. Mir-106b-5p expression in the blood was proposed as an ADD biomarker and predicted ADD with $93 \%$ specificity and $68 \%$ sensitivity [124]. Let-7a-5p is proposed as an ADD blood biomarker and its expression is downregulated [125]. MiRNAs belonging to the mir-20a family, such as mir-17-5p, could regulate APP expression [126]. Mir-17 is upregulated in the serum of patients with multiple system atrophy [127]. Mir-155 is triplicated in Down syndrome [128,129]. It has been proposed that mir-155 upregulation is correlated with Down syndrome dementia $[130,131]$. Mir-155 plays a role in regulating the memory impairment in ADD rats [132]. It has been proposed that mir-155 contributes to ADD neuroinflammation [133,134]. Mir-155-5p and mir-26b-5p expression is altered in ADD mouse models and in patients $[135,136]$. Interestingly, mir-155-5p is also upregulated in the blood of PD patients, indicating that this miRNA might have a general role in neurodegeneration [137]. Similar to our study, a network analysis identified mir-20a, mir-17, mir-155, mir-18, and mir-106b as potential regulators of the expression genes that are altered in an ADD mouse model [138]. Only one miRNA, mir-335-5p, was specific to ADD, suggesting that it may be useful as an ADD biomarker.

\subsection{Limitations}

As in all microarray and meta-analyses, our study has some limitations. The sample sizes of each microarray study will affect the power of our analysis. Regarding this, we have selected only the microarray data sets that have five or more patients or controls for our meta-analysis. Analysis of additional datasets when they become available is expected to provide information that will be useful for determining if our results may be replicated. The microarray data sets that were used in this study are heterogeneous because they came from multiple studies using different conditions and number of samples. In order to minimize the effect of this heterogeneity, we only used studies that were curated by the BSCE database, which controls for the quality and normalization of the data. Genes of which their mean normalized test and control intensities were both less than the $20^{\text {th }}$ percentile of the combined normalized signal intensities were removed.

Our analyses were performed based on publicly available data. The site-to-site variability may influence the identification of dysregulated genes. Whereas the methodology of blood collection and RNA preparation is often similar, the diagnostic criteria might be variable between the different studies performed in the USA, Europe, and Brazil. For example, with a deeper understanding of the disease, the National Institute of Aging (NIA) in the USA has revised the clinical diagnostic guidelines several times. For research purposes, it has been proposed to define the research cohort based on biological criteria. The use of cognitive tests to identify the healthy population instead of biological tests might have been the best approach at the time the original study was done. It is possible, therefore, that some healthy controls might be preclinical MCI or ADD patients. In this regard, it has been estimated that $30-40 \%$ of cognitively normal individuals have some sign of neuropathological brain changes at autopsy [139].

Another limitation of this study is that patient information in general was incomplete and often restricted to age. Other factors, such as genetic determinants, comorbidities, and an individual's lifestyle choices, most likely influence gene expression, but this information was not available. For example, the presence of ApoE4, the most common risk factor of $\mathrm{ADD}$, is often missing from the patients' profiles. ADD is strongly associated with vascular disease or vascular risk factors [140]. In addition, mid-life elevated blood pressure may increase the risk of ADD later in life [141]. Another well documented risk to develop ADD is diabetes mellitus [142]. Impaired glucose tolerance and ADD have been correlated in different patient studies [143-145]. Finally, an association has also been observed between ADD and low bone mineral density or osteoporosis [146]. Information such as blood pressure, glucose levels, thyroid hormone levels, bone mineral density, and comorbidities would be interesting to collect in future studies in order to determine if they affect gene expression in the blood. 
Other information that was unfortunately missing from the patients was their concomitant medications. We compared the MCI and ADD genes that were identified in this study to the genes that were targeted by the approved or investigational ADD drugs [147]. S100P, which is present in both MCI and ADD, could be targeted by the investigational drug ALZT-OP1a/b. Among the ADD specific-gene, CA1 could be targeted by calcium channel blockers, whereas SNCA could be targeted by Resveratrol. The patients in the ADD cohorts may be receiving different medications to alleviate their symptoms such as BDZ, barbiturates, mood stabilizers (valproate, lamotrigine, etc), SSRI, NNRI, mixed effect compounds, and neuroleptics. In addition, they could also be taking drugs for other conditions. All these drugs have the potential to dysregulate gene expression and potentially alter the results of this study. However, it should be noted that many genes that found to be altered in MCI were also altered in early ADD, suggesting a common mechanism and relevance to disease pathogenesis. Further studies should incorporate the patients' medications in the characteristics.

ADD is now considered a continuum rather than a disease and is divided into three distinct stages of presymptomatic, MCI, and ADD. Further analysis could include correlation analysis of key gene expression data with biological or cognitive results. Longitudinal cohort studies will be necessary to better understand the correlation between potential RNA biomarkers and the signs or symptoms of the disease.

\section{Materials and Methods}

\subsection{Analysis of Blood Transcriptomic Studies}

We used the curated database BaseSpace Correlation Engine (BSCE, Illumina, Inc., San Diego, CA, USA) to search for gene expression studies in MCI, ADD, and advanced ADD [148]. Using the search terms "Alzheimer's disease", "mild cognitive impairment", "blood", "human", "RNA", and "microarray", we identified three studies with blood from MCI and ADD patients. Only human microarray studies with five samples or more for cases and controls and that were curated in BSCE were considered for analysis. Two studies on ADD patients were removed because they contained less than five samples. Six microarrays met our inclusion criteria as of July 1, 2019. A description of microarray datasets that were included in this study is provided in Table 1.

The diagnosis of ADD subjects in GSE63063 was performed according to guidelines from the National Institute of Neurological and Communicative Disease and Stroke and Alzheimer's disease (NINCDS-ADRDA) and Diagnostic and Statistical Manual of Mental Disorders (DSM-IV) [43-45]. Subjects with MCI reported problems with memory, corroborated by an informant, but had normal activities of daily living as specified in the Petersen's criteria for amnestic MCI. MCI subjects scored 0.5 on the total Clinical Dementia Rating Scale or had a memory score of 0.5 to 1 . All subjects underwent a structured interview and a battery of neuropsychological assessments including the Mini Mental State Examination (MMSE), Global Deterioration Scale (GDS), and Clinical Dementia Rating Scale (CDR) by trained researchers. Healthy controls and MCI subjects were further assessed using the Consortium to Establish a Registry for Alzheimer's Disease (CERAD) battery. The MCI cohort was composed largely of subjects with a likely ADD-endpoint. Subjects were excluded from the study if they were younger than 65 years, had significant neurological or psychiatric illness other than ADD, had significant systematic illness or organ failure, or had a geriatric depression rating scale score $\geq 4 / 5$. More details can be found in the literature [43-45]. Subjects in the dataset GSE97760 were all female, including patients with advanced $\operatorname{ADD}(n=9$, age $79.3 \pm 12.3$ years $)$ and age-matched female healthy controls ( $n=10$, age $72.1 \pm 13.1$ years) [46]. The ADD diagnoses were made by the Neurobehavior and Memory Disorders Clinic at the Ohio State University Wexner Medical Center (NMDC-OSUWMC), following the revised NIH Diagnostic Guidelines for Alzheimer's disease and Related Disorders [46]. All recruited ADD subjects were nursing home residents and were completely dependent or bed-ridden, with a severe clinical dementia rating of 2 to 3 at the time of recruitment. Healthy controls were recruited among female spouses and primary caregivers of afflicted male 
dementia patients seen at MDC-OSUWMC, and were free of dementia, acute or chronic infection, inflammation, and diabetes. More details can be found in [46]. Information about the diagnosis of ADD patients from E-MTAB-6094 is not available. Subjects in the dataset E-MTAB-6094 were 14 female and 8 male patients with ADD $(n=22$, age $79.4 \pm 6.6$ years $)$ and 10 female and 3 male age-matched healthy controls $(n=13$, age $77.3 \pm 6.2$ years). All ADD patients were diagnosed based on the criteria established by the Diagnostic and Statistical Manual of Mental Disorders 4th edition and the National Institute of Neurological and Communicative Disorders and Stroke and The Alzheimer's disease Related disorders Association. Due to the lack of neuropathological exams, patients were classified as having probable Alzheimer's disease.

The differentially expressed genes were curated by BSCE. Statistical analyses were performed on $\log$ scale data. In the parametric test, variances were not assumed equal (Welch $t$-test). A $p$-value cutoff of 0.05 and fold change of 1.2 was applied to generate the final list of genes. Genes of which their mean normalized test and control intensities are both less than the $20^{\text {th }}$ percentile of the combined normalized signal intensities were removed. Final gene expression data from microarray studies were downloaded from BSCE (Table S1). A Venn diagram analysis was performed with the genes that were up or downregulated in the two MCI arrays and the four ADD arrays independently. The transcription factors Venn diagram was created using the website http://bioinformatics.psb.ugent.be/webtools/Venn/, whereas the UpSetR diagram was created using the website https:/gehlenborglab.shinyapps.io/ upsetr/ [149]. Only genes that were differentially expressed in both MCI arrays and in at least two ADD studies were included for further analysis.

\subsection{Pathway Enrichment Analysis}

An official gene symbol from the genes that were identified in the meta-analyses were imported into NetworkAnalyst 3.0 for pathway analyses $[150,151]$. The Kyoto Encyclopedia of Genes and Genome (KEGG) pathway database was used as annotation sources [152].

\subsection{Gene-Transcription Factors Interaction Analysis}

Gene-transcription factors interactome was performed in NetworkAnalyst. Transcription factor and gene target data were derived from the Encyclopedia of DNA Elements (ENCODE) ChIP-seq data, ChIP Enrichment Analysis (ChEA), or JASPAR database [153-155]. ENCODE uses the BETA Minus Algorithm in which only peak intensity signal $<500$ and the predicted regulatory potential score $<1$ is used. ChEA transcription factor targets databases that are inferred from integrating literature curated Chip-X data. JASPAR is an open-access database of curated, non-redundant transcription factor (TF)-binding profiles. A Venn diagram analysis was performed with the transcription factors that were identified with each database. Transcription factors were ranked according to network topology measurements including degree and betweenness centrality.

\subsection{Gene-miRNA Interaction Analysis}

The gene-miRNA interactome was performed in NetworkAnalyst. The Gene-miRNA Interactome was carried out from comprehensive experimentally validated miRNA-gene interaction data collected from TarBase and miRTarBase [156-158].

\subsection{Gene-Disease Association Analysis}

Gene-disease association analysis was performed in NetworkAnalyst. The literature curated gene-disease association information was collected from the DisGeNET database, a publicly available collections of genes and variants that are associated with human diseases [159]. 


\section{Conclusions}

Collectively, the results that are presented in this study reveal the characteristics that are shared between MCI and ADD. Most of the genes and pathways are already dysregulated in the early preclinical phase of ADD, suggesting the importance of an earlier diagnostic tool. During MCI, genes that are involved in neurodegeneration, ribosome function, oxidative phosphorylation, non-alcoholic fatty liver disease, and cardiac muscle contraction are dysregulated and most likely influence the early stages of pathology. Other pathways, such as viral and bacterial infection, proteasome function, collecting duct acid secretion, spliceosome function, and nucleotide excision repair were specific to ADD and might play a role in the later stages of disease development. In this study, we also identified putative transcriptional and miRNA regulators of MCI and ADD gene expression. Whereas 15 transcription factors might be involved in both MCI and ADD development, seven transcription factors might be involved later in ADD progression. In addition, mir-335-5p was specific for ADD, suggesting that it may be useful as a biomarker.

Supplementary Materials: The following are available online at http://www.mdpi.com/1422-0067/20/21/5403/s1, Table S1. Genes differentially expressed in each arrays. Table S2. Shared genes between the MCI arrays and the ADD arrays. Table S3. Specific and shared genes from the MCI and ADD meta-analysis. Table S4. Genes in each pathway. Table S5. Associated disease. Figure S1: UpsetR analysis of the genes down and up regulated in MCI (A and B, respectively) and of the genes down and up regulated in ADD (C and D, respectively). The UpSetR diagram was created using https://gehlenborglab.shinyapps.io/upsetr/.

Author Contributions: V.B. and J.A.P. conceived and designed the study, analyzed the data, wrote the paper, and contributed to the designs of the methods that were used in this study. All authors have read and approved the final version of the manuscript.

Funding: This study was funded by the National Institute on Aging (NIA) grant number R01AG062176 to J.A.P.

Conflicts of Interest: The authors have no conflict of interest to report. The funders had no role in the design of the study; in the collection, analyses, or interpretation of data; in the writing of the manuscript, or in the decision to publish the results.

\section{References}

1. Robinson, L.; Tang, E.; Taylor, J.P. Dementia: Timely diagnosis and early intervention. BMJ 2015, 350 , h3029. [CrossRef] [PubMed]

2. Jack, C.R., Jr.; Bennett, D.A.; Blennow, K.; Carrillo, M.C.; Dunn, B.; Haeberlein, S.B.; Holtzman, D.M.; Jagust, W.; Jessen, F.; Karlawish, J.; et al. NIA-AA Research Framework: Toward a biological definition of Alzheimer's disease. Alzheimers Dement. 2018, 14, 535-562. [CrossRef] [PubMed]

3. Jack, C.R., Jr.; Therneau, T.M.; Weigand, S.D.; Wiste, H.J.; Knopman, D.S.; Vemuri, P.; Lowe, V.J.; Mielke, M.M.; Roberts, R.O.; Machulda, M.M.; et al. Prevalence of Biologically vs Clinically Defined Alzheimer Spectrum Entities Using the National Institute on Aging-Alzheimer's Association Research Framework. JAMA Neurol. 2019, 76, 1174-1183. [CrossRef] [PubMed]

4. Raber, J.; Huang, Y.; Ashford, J.W. ApoE genotype accounts for the vast majority of AD risk and AD pathology. Neurobiol. Aging 2004, 25, 641-650. [CrossRef]

5. Bennett, D.A.; Wilson, R.S.; Schneider, J.A.; Evans, D.A.; Aggarwal, N.T.; Arnold, S.E.; Cochran, E.J.; Berry-Kravis, E.; Bienias, J.L. Apolipoprotein E epsilon4 allele, AD pathology, and the clinical expression of Alzheimer's disease. Neurology 2003, 60, 246-252. [CrossRef]

6. Bennett, D.A.; Schneider, J.A.; Wilson, R.S.; Bienias, J.L.; Berry-Kravis, E.; Arnold, S.E. Amyloid mediates the association of apolipoprotein E e4 allele to cognitive function in older people. J. Neurol. Neurosurg. Psychiatry 2005, 76, 1194-1199. [CrossRef]

7. Karch, C.M.; Cruchaga, C.; Goate, A.M. Alzheimer's disease genetics: From the bench to the clinic. Neuron 2014, 83, 11-26. [CrossRef]

8. Van Cauwenberghe, C.; Van Broeckhoven, C.; Sleegers, K. The genetic landscape of Alzheimer disease: Clinical implications and perspectives. Genet. Med. 2016, 18, 421-430. [CrossRef] 
9. Jansen, I.E.; Savage, J.E.; Watanabe, K.; Bryois, J.; Williams, D.M.; Steinberg, S.; Sealock, J.; Karlsson, I.K.; Hagg, S.; Athanasiu, L.; et al. Genome-wide meta-analysis identifies new loci and functional pathways influencing Alzheimer's disease risk. Nat. Genet. 2019, 51, 404-413. [CrossRef]

10. Extance, A. Alzheimer's failure raises questions about disease-modifying strategies. Nat. Rev. Drug Discov. 2010, 9, 749-751. [CrossRef]

11. Alzheimer's, A. Alzheimer's disease facts and figures. Alzheimers Dement. 2011, 7, 208-244. [CrossRef]

12. Sperling, R.A.; Aisen, P.S.; Beckett, L.A.; Bennett, D.A.; Craft, S.; Fagan, A.M.; Iwatsubo, T.; Jack, C.R., Jr.; Kaye, J.; Montine, T.J.; et al. Toward defining the preclinical stages of Alzheimer's disease: Recommendations from the National Institute on Aging-Alzheimer's Association workgroups on diagnostic guidelines for Alzheimer's disease. Alzheimers Dement. 2011, 7, 280-292. [CrossRef] [PubMed]

13. Jack, C.R., Jr.; Knopman, D.S.; Jagust, W.J.; Shaw, L.M.; Aisen, P.S.; Weiner, M.W.; Petersen, R.C.; Trojanowski, J.Q. Hypothetical model of dynamic biomarkers of the Alzheimer's pathological cascade. Lancet Neurol. 2010, 9, 119-128. [CrossRef]

14. Tang, Y.; Gilbert, D.L.; Glauser, T.A.; Hershey, A.D.; Sharp, F.R. Blood gene expression profiling of neurologic diseases: A pilot microarray study. Arch. Neurol. 2005, 62, 210-215. [CrossRef] [PubMed]

15. Blennow, K.; Hampel, H.; Weiner, M.; Zetterberg, H. Cerebrospinal fluid and plasma biomarkers in Alzheimer disease. Nat. Rev. Neurol. 2010, 6, 131-144. [CrossRef] [PubMed]

16. Courtney, E.; Kornfeld, S.; Janitz, K.; Janitz, M. Transcriptome profiling in neurodegenerative disease. J. Neurosci. Methods 2010, 193, 189-202. [CrossRef]

17. Wu, Y.; Le, W.; Jankovic, J. Preclinical biomarkers of Parkinson disease. Arch. Neurol. 2011, 68, 22-30. [CrossRef]

18. Leuner, K.; Schulz, K.; Schutt, T.; Pantel, J.; Prvulovic, D.; Rhein, V.; Savaskan, E.; Czech, C.; Eckert, A.; Muller, W.E. Peripheral mitochondrial dysfunction in Alzheimer's disease: Focus on lymphocytes. Mol. Neurobiol. 2012, 46, 194-204. [CrossRef]

19. Santiago, J.A.; Potashkin, J.A. A network approach to clinical intervention in neurodegenerative diseases. Trends Mol. Med. 2014, 20, 694-703. [CrossRef]

20. Soler-Lopez, M.; Zanzoni, A.; Lluis, R.; Stelzl, U.; Aloy, P. Interactome mapping suggests new mechanistic details underlying Alzheimer's disease. Genome Res. 2011, 21, 364-376. [CrossRef]

21. Zhang, B.; Gaiteri, C.; Bodea, L.G.; Wang, Z.; McElwee, J.; Podtelezhnikov, A.A.; Zhang, C.; Xie, T.; Tran, L.; Dobrin, R.; et al. Integrated systems approach identifies genetic nodes and networks in late-onset Alzheimer's disease. Cell 2013, 153, 707-720. [CrossRef] [PubMed]

22. Miller, J.A.; Woltjer, R.L.; Goodenbour, J.M.; Horvath, S.; Geschwind, D.H. Genes and pathways underlying regional and cell type changes in Alzheimer's disease. Genome Med. 2013, 5, 48. [CrossRef] [PubMed]

23. Wang, M.; Roussos, P.; McKenzie, A.; Zhou, X.; Kajiwara, Y.; Brennand, K.J.; De Luca, G.C.; Crary, J.F.; Casaccia, P.; Buxbaum, J.D.; et al. Integrative network analysis of nineteen brain regions identifies molecular signatures and networks underlying selective regional vulnerability to Alzheimer's disease. Genome Med. 2016, 8, 104. [CrossRef] [PubMed]

24. Grothe, M.J.; Sepulcre, J.; Gonzalez-Escamilla, G.; Jelistratova, I.; Scholl, M.; Hansson, O.; Teipel, S.J. Molecular properties underlying regional vulnerability to Alzheimer's disease pathology. Brain 2018, 141, 2755-2771. [CrossRef]

25. Liang, D.; Han, G.; Feng, X.; Sun, J.; Duan, Y.; Lei, H. Concerted perturbation observed in a hub network in Alzheimer's disease. PLoS ONE 2012, 7, e40498. [CrossRef]

26. Kikuchi, M.; Ogishima, S.; Miyamoto, T.; Miyashita, A.; Kuwano, R.; Nakaya, J.; Tanaka, H. Identification of unstable network modules reveals disease modules associated with the progression of Alzheimer's disease. PLoS ONE 2013, 8, e76162. [CrossRef]

27. Lau, P.; Bossers, K.; Janky, R.; Salta, E.; Frigerio, C.S.; Barbash, S.; Rothman, R.; Sierksma, A.S.; Thathiah, A.; Greenberg, D.; et al. Alteration of the microRNA network during the progression of Alzheimer's disease. EMBO Mol. Med. 2013, 5, 1613-1634. [CrossRef]

28. Hallock, P.; Thomas, M.A. Integrating the Alzheimer's disease proteome and transcriptome: A comprehensive network model of a complex disease. Omics J. Integr. Biol. 2012, 16, 37-49. [CrossRef]

29. Raj, T.; Shulman, J.M.; Keenan, B.T.; Chibnik, L.B.; Evans, D.A.; Bennett, D.A.; Stranger, B.E.; De Jager, P.L. Alzheimer disease susceptibility loci: Evidence for a protein network under natural selection. Am. J. Hum. Genet. 2012, 90, 720-726. [CrossRef] 
30. Talwar, P.; Silla, Y.; Grover, S.; Gupta, M.; Agarwal, R.; Kushwaha, S.; Kukreti, R. Genomic convergence and network analysis approach to identify candidate genes in Alzheimer's disease. BMC Genom. 2014, 15, 199. [CrossRef]

31. Ciryam, P.; Kundra, R.; Freer, R.; Morimoto, R.I.; Dobson, C.M.; Vendruscolo, M. A transcriptional signature of Alzheimer's disease is associated with a metastable subproteome at risk for aggregation. Proc. Natl. Acad. Sci. USA 2014, 113, 4753-4758. [CrossRef] [PubMed]

32. Su, L.; Chen, S.; Zheng, C.; Wei, H.; Song, X. Meta-Analysis of Gene Expression and Identification of Biological Regulatory Mechanisms in Alzheimer's Disease. Front. Neurosci. 2019, 13, 633. [CrossRef] [PubMed]

33. Moradifard, S.; Hoseinbeyki, M.; Ganji, S.M.; Minuchehr, Z. Analysis of microRNA and Gene Expression Profiles in Alzheimer's Disease: A Meta-Analysis Approach. Sci. Rep. 2018, 8, 4767. [CrossRef] [PubMed]

34. Puthiyedth, N.; Riveros, C.; Berretta, R.; Moscato, P. Identification of Differentially Expressed Genes through Integrated Study of Alzheimer's Disease Affected Brain Regions. PLoS ONE 2016, 11, e0152342. [CrossRef] [PubMed]

35. Wruck, W.; Schroter, F.; Adjaye, J. Meta-Analysis of Transcriptome Data Related to Hippocampus Biopsies and iPSC-Derived Neuronal Cells from Alzheimer's Disease Patients Reveals an Association with FOXA1 and FOXA2 Gene Regulatory Networks. J. Alzheimers Dis. 2016, 50, 1065-1082. [CrossRef]

36. Barbash, S.; Soreq, H. Threshold-independent meta-analysis of Alzheimer's disease transcriptomes shows progressive changes in hippocampal functions, epigenetics and microRNA regulation. Curr. Alzheimer Res. 2012, 9, 425-435. [CrossRef]

37. Zhang, L.; Hu, J.; Hao, M.; Bu, L. Long noncoding RNA Linc01296 promotes hepatocellular carcinoma development through regulation of the miR-26a/PTEN axis. Biol. Chem. 2019. [CrossRef]

38. Patel, H.; Dobson, R.J.B.; Newhouse, S.J. A Meta-Analysis of Alzheimer's Disease Brain Transcriptomic Data. J. Alzheimers Dis. 2019, 68, 1635-1656. [CrossRef]

39. Kelly, J.; Moyeed, R.; Carroll, C.; Albani, D.; Li, X. Gene expression meta-analysis of Parkinson's disease and its relationship with Alzheimer's disease. Mol. Brain 2019, 12, 16. [CrossRef]

40. Wei, C.J.; Cui, P.; Li, H.; Lang, W.J.; Liu, G.Y.; Ma, X.F. Shared genes between Alzheimer's disease and ischemic stroke. CNS Neurosci. Ther. 2019, 25, 855-864. [CrossRef]

41. Mirza, Z.; Kamal, M.A.; Buzenadah, A.M.; Al-Qahtani, M.H.; Karim, S. Establishing genomic/transcriptomic links between Alzheimer's disease and type 2 diabetes mellitus by meta-analysis approach. CNS Neurol. Disord. Drug Targets 2014, 13, 501-516. [CrossRef] [PubMed]

42. Caberlotto, L.; Nguyen, T.P.; Lauria, M.; Priami, C.; Rimondini, R.; Maioli, S.; Cedazo-Minguez, A.; Sita, G.; Morroni, F.; Corsi, M.; et al. Cross-disease analysis of Alzheimer's disease and type-2 Diabetes highlights the role of autophagy in the pathophysiology of two highly comorbid diseases. Sci. Rep. 2019, 9, 3965. [CrossRef]

43. Sood, S.; Gallagher, I.J.; Lunnon, K.; Rullman, E.; Keohane, A.; Crossland, H.; Phillips, B.E.; Cederholm, T.; Jensen, T.; van Loon, L.J.; et al. A novel multi-tissue RNA diagnostic of healthy ageing relates to cognitive health status. Genome Biol. 2015, 16, 185. [CrossRef]

44. Lunnon, K.; Sattlecker, M.; Furney, S.J.; Coppola, G.; Simmons, A.; Proitsi, P.; Lupton, M.K.; Lourdusamy, A.; Johnston, C.; Soininen, H.; et al. A blood gene expression marker of early Alzheimer's disease. J. Alzheimers Dis. 2013, 33, 737-753. [CrossRef] [PubMed]

45. Lunnon, K.; Ibrahim, Z.; Proitsi, P.; Lourdusamy, A.; Newhouse, S.; Sattlecker, M.; Furney, S.; Saleem, M.; Soininen, H.; Kloszewska, I.; et al. Mitochondrial dysfunction and immune activation are detectable in early Alzheimer's disease blood. J. Alzheimers Dis. 2012, 30, 685-710. [CrossRef] [PubMed]

46. Naughton, B.J.; Duncan, F.J.; Murrey, D.A.; Meadows, A.S.; Newsom, D.E.; Stoicea, N.; White, P.; Scharre, D.W.; McCarty, D.M.; Fu, H. Blood genome-wide transcriptional profiles reflect broad molecular impairments and strong blood-brain links in Alzheimer's disease. J. Alzheimers Dis. 2015, 43, 93-108. [CrossRef]

47. Ferrarese, C.; Appollonio, I.; Frigo, M.; Meregalli, S.; Piolti, R.; Tamma, F.; Frattola, L. Cerebrospinal fluid levels of diazepam-binding inhibitor in neurodegenerative disorders with dementia. Neurology 1990, 40, 632-635. [CrossRef]

48. Edgar, P.F.; Schonberger, S.J.; Dean, B.; Faull, R.L.; Kydd, R.; Cooper, G.J. A comparative proteome analysis of hippocampal tissue from schizophrenic and Alzheimer's disease individuals. Mol. Psychiatry 1999, 4, 173-178. [CrossRef]

49. Mills, J.D.; Nalpathamkalam, T.; Jacobs, H.I.; Janitz, C.; Merico, D.; Hu, P.; Janitz, M. RNA-Seq analysis of the parietal cortex in Alzheimer's disease reveals alternatively spliced isoforms related to lipid metabolism. Neurosci. Lett. 2013, 536, 90-95. [CrossRef] 
50. Manners, H.N.; Roy, S.; Kalita, J.K. Intrinsic-overlapping co-expression module detection with application to Alzheimer's Disease. Comput. Biol. Chem. 2018, 77, 373-389. [CrossRef]

51. Adav, S.S.; Park, J.E.; Sze, S.K. Quantitative profiling brain proteomes revealed mitochondrial dysfunction in Alzheimer's disease. Mol. Brain 2019, 12, 8. [CrossRef] [PubMed]

52. Armand-Ugon, M.; Ansoleaga, B.; Berjaoui, S.; Ferrer, I. Reduced Mitochondrial Activity is Early and Steady in the Entorhinal Cortex but it is Mainly Unmodified in the Frontal Cortex in Alzheimer's Disease. Curr. Alzheimer Res. 2017, 14, 1327-1334. [CrossRef] [PubMed]

53. Mastroeni, D.; Grover, A.; Delvaux, E.; Whiteside, C.; Coleman, P.D.; Rogers, J. Epigenetic changes in Alzheimer's disease: Decrements in DNA methylation. Neurobiol. Aging 2010, 31, 2025-2037. [CrossRef] [PubMed]

54. Mirzaei, M.; Pushpitha, K.; Deng, L.; Chitranshi, N.; Gupta, V.; Rajput, R.; Mangani, A.B.; Dheer, Y.; Godinez, A.; McKay, M.J.; et al. Upregulation of Proteolytic Pathways and Altered Protein Biosynthesis Underlie Retinal Pathology in a Mouse Model of Alzheimer's Disease. Mol. Neurobiol. 2019, 56, 6017-6034. [CrossRef] [PubMed]

55. Li, X.; Wang, H.; Long, J.; Pan, G.; He, T.; Anichtchik, O.; Belshaw, R.; Albani, D.; Edison, P.; Green, E.K.; et al. Systematic Analysis and Biomarker Study for Alzheimer's Disease. Sci. Rep. 2018, 8, 17394. [CrossRef] [PubMed]

56. Shen, L.; Liao, L.; Chen, C.; Guo, Y.; Song, D.; Wang, Y.; Chen, Y.; Zhang, K.; Ying, M.; Li, S.; et al. Proteomics Analysis of Blood Serums from Alzheimer's Disease Patients Using iTRAQ Labeling Technology. J. Alzheimers Dis. 2017, 56, 361-378. [CrossRef] [PubMed]

57. Hagmeyer, S.; Romao, M.A.; Cristovao, J.S.; Vilella, A.; Zoli, M.; Gomes, C.M.; Grabrucker, A.M. Distribution and Relative Abundance of S100 Proteins in the Brain of the APP23 Alzheimer's Disease Model Mice. Front. Neurosci. 2019, 13, 640. [CrossRef]

58. Di Domenico, F.; Sultana, R.; Tiu, G.F.; Scheff, N.N.; Perluigi, M.; Cini, C.; Butterfield, D.A. Protein levels of heat shock proteins 27, 32, 60, 70, 90 and thioredoxin-1 in amnestic mild cognitive impairment: An investigation on the role of cellular stress response in the progression of Alzheimer disease. Brain Res. 2010, 1333, 72-81. [CrossRef]

59. Lovell, M.A.; Xie, C.; Gabbita, S.P.; Markesbery, W.R. Decreased thioredoxin and increased thioredoxin reductase levels in Alzheimer's disease brain. Free Radic. Biol. Med. 2000, 28, 418-427. [CrossRef]

60. Arodin, L.; Lamparter, H.; Karlsson, H.; Nennesmo, I.; Bjornstedt, M.; Schroder, J.; Fernandes, A.P. Alteration of thioredoxin and glutaredoxin in the progression of Alzheimer's disease. J. Alzheimers Dis. 2014, 39, 787-797. [CrossRef]

61. Akterin, S.; Cowburn, R.F.; Miranda-Vizuete, A.; Jimenez, A.; Bogdanovic, N.; Winblad, B.; Cedazo-Minguez, A. Involvement of glutaredoxin-1 and thioredoxin-1 in beta-amyloid toxicity and Alzheimer's disease. Cell Death Differ. 2006, 13, 1454-1465. [CrossRef] [PubMed]

62. Xu, W.; Cao, M.; Zheng, H.; Tan, X.; Li, L.; Cui, G.; Xu, J.; Cao, J.; Ke, K.; Wu, Q. Upregulation of SYF2 is associated with neuronal apoptosis caused by reactive astrogliosis to neuroinflammation. J. Neurosci. Res. 2014, 92, 318-328. [CrossRef] [PubMed]

63. Lee, J.K.; McCoy, M.K.; Harms, A.S.; Ruhn, K.A.; Gold, S.J.; Tansey, M.G. Regulator of G-protein signaling 10 promotes dopaminergic neuron survival via regulation of the microglial inflammatory response. J. Neurosci. 2008, 28, 8517-8528. [CrossRef] [PubMed]

64. Rahman, M.R.; Islam, T.; Zaman, T.; Shahjaman, M.; Karim, M.R.; Huq, F.; Quinn, J.M.W.; Holsinger, R.M.D.; Gov, E.; Moni, M.A. Identification of molecular signatures and pathways to identify novel therapeutic targets in Alzheimer's disease: Insights from a systems biomedicine perspective. Genomics 2019. [CrossRef] [PubMed]

65. Rahman, M.R.; Islam, T.; Turanli, B.; Zaman, T.; Faruquee, H.M.; Rahman, M.M.; Mollah, M.N.H.; Nanda, R.K.; Arga, K.Y.; Gov, E.; et al. Network-based approach to identify molecular signatures and therapeutic agents in Alzheimer's disease. Comput. Biol. Chem. 2019, 78, 431-439. [CrossRef] [PubMed]

66. Hernandez-Ortega, K.; Garcia-Esparcia, P.; Gil, L.; Lucas, J.J.; Ferrer, I. Altered Machinery of Protein Synthesis in Alzheimer's: From the Nucleolus to the Ribosome. Brain Pathol. 2016, 26, 593-605. [CrossRef]

67. Ding, Q.; Markesbery, W.R.; Chen, Q.; Li, F.; Keller, J.N. Ribosome dysfunction is an early event in Alzheimer's disease. J. Neurosci. 2005, 25, 9171-9175. [CrossRef]

68. Meier, S.; Bell, M.; Lyons, D.N.; Rodriguez-Rivera, J.; Ingram, A.; Fontaine, S.N.; Mechas, E.; Chen, J.; Wolozin, B.; LeVine, H., 3rd; et al. Pathological Tau Promotes Neuronal Damage by Impairing Ribosomal Function and Decreasing Protein Synthesis. J. Neurosci. 2016, 36, 1001-1007. [CrossRef] 
69. He, K.; Nie, L.; Zhou, Q.; Rahman, S.U.; Liu, J.; Yang, X.; Li, S. Proteomic Profiles of the Early Mitochondrial Changes in APP/PS1 and ApoE4 Transgenic Mice Models of Alzheimer's Disease. J. Proteome Res. 2019, 18, 2632-2642. [CrossRef]

70. Lanzillotta, C.; Di Domenico, F.; Perluigi, M.; Butterfield, D.A. Targeting Mitochondria in Alzheimer Disease: Rationale and Perspectives. CNS Drugs 2019. [CrossRef]

71. Gibson, G.E.; Shi, Q. A mitocentric view of Alzheimer's disease suggests multi-faceted treatments. J. Alzheimers Dis. 2010, 20 (Suppl. 2), S591-S607. [CrossRef]

72. Delbarba, A.; Abate, G.; Prandelli, C.; Marziano, M.; Buizza, L.; Arce Varas, N.; Novelli, A.; Cuetos, F.; Martinez, C.; Lanni, C.; et al. Mitochondrial Alterations in Peripheral Mononuclear Blood Cells from Alzheimer's Disease and Mild Cognitive Impairment Patients. Oxid. Med. Cell. Longev. 2016, 2016, 5923938. [CrossRef] [PubMed]

73. Wang, Y.R.; Wang, Q.H.; Zhang, T.; Liu, Y.H.; Yao, X.Q.; Zeng, F.; Li, J.; Zhou, F.Y.; Wang, L.; Yan, J.C.; et al. Associations Between Hepatic Functions and Plasma Amyloid-Beta Levels-Implications for the Capacity of Liver in Peripheral Amyloid-Beta Clearance. Mol. Neurobiol. 2017, 54, 2338-2344. [CrossRef] [PubMed]

74. Seo, S.W.; Gottesman, R.F.; Clark, J.M.; Hernaez, R.; Chang, Y.; Kim, C.; Ha, K.H.; Guallar, E.; Lazo, M. Nonalcoholic fatty liver disease is associated with cognitive function in adults. Neurology 2016, 86, 1136-1142. [CrossRef] [PubMed]

75. Astarita, G.; Jung, K.M.; Berchtold, N.C.; Nguyen, V.Q.; Gillen, D.L.; Head, E.; Cotman, C.W.; Piomelli, D. Deficient liver biosynthesis of docosahexaenoic acid correlates with cognitive impairment in Alzheimer's disease. PLoS ONE 2010, 5, e12538. [CrossRef] [PubMed]

76. Li, D.; Parks, S.B.; Kushner, J.D.; Nauman, D.; Burgess, D.; Ludwigsen, S.; Partain, J.; Nixon, R.R.; Allen, C.N.; Irwin, R.P.; et al. Mutations of presenilin genes in dilated cardiomyopathy and heart failure. Am. J. Hum. Genet. 2006, 79, 1030-1039. [CrossRef]

77. Turdi, S.; Guo, R.; Huff, A.F.; Wolf, E.M.; Culver, B.; Ren, J. Cardiomyocyte contractile dysfunction in the APPswe/PS1dE9 mouse model of Alzheimer's disease. PLoS ONE 2009, 4, e6033. [CrossRef]

78. Kim, T.W.; Song, I.U.; Jeong, D.S.; Lee, K.S. Clinical effect of cerebrovascular atherosclerosis on cognition in Alzheimer's disease. Arch. Gerontol. Geriatr. 2016, 63, 55-58. [CrossRef]

79. Hong, L.; Huang, H.C.; Jiang, Z.F. Relationship between amyloid-beta and the ubiquitin-proteasome system in Alzheimer's disease. Neurol. Res. 2014, 36, 276-282. [CrossRef]

80. Riederer, B.M.; Leuba, G.; Vernay, A.; Riederer, I.M. The role of the ubiquitin proteasome system in Alzheimer's disease. Exp. Biol. Med. 2011, 236, 268-276. [CrossRef]

81. Almeida, C.G.; Takahashi, R.H.; Gouras, G.K. Beta-amyloid accumulation impairs multivesicular body sorting by inhibiting the ubiquitin-proteasome system. J. Neurosci. 2006, 26, 4277-4288. [CrossRef] [PubMed]

82. Zhao, X.; Yang, J. Amyloid-beta peptide is a substrate of the human 20S proteasome. ACS Chem. Neurosci. 2010, 1, 655-660. [CrossRef] [PubMed]

83. Gregori, L.; Hainfeld, J.F.; Simon, M.N.; Goldgaber, D. Binding of amyloid beta protein to the $20 \mathrm{~S}$ proteasome. J. Biol. Chem. 1997, 272, 58-62. [CrossRef] [PubMed]

84. Lopez Salon, M.; Pasquini, L.; Besio Moreno, M.; Pasquini, J.M.; Soto, E. Relationship between beta-amyloid degradation and the $26 \mathrm{~S}$ proteasome in neural cells. Exp. Neurol. 2003, 180, 131-143. [CrossRef]

85. Diner, I.; Hales, C.M.; Bishof, I.; Rabenold, L.; Duong, D.M.; Yi, H.; Laur, O.; Gearing, M.; Troncoso, J.; Thambisetty, M.; et al. Aggregation properties of the small nuclear ribonucleoprotein U1-70K in Alzheimer disease. J. Biol. Chem. 2014, 289, 35296-35313. [CrossRef] [PubMed]

86. Bai, B.; Hales, C.M.; Chen, P.C.; Gozal, Y.; Dammer, E.B.; Fritz, J.J.; Wang, X.; Xia, Q.; Duong, D.M.; Street, C.; et al. U1 small nuclear ribonucleoprotein complex and RNA splicing alterations in Alzheimer's disease. Proc. Natl. Acad. Sci. USA 2013, 110, 16562-16567. [CrossRef]

87. Hales, C.M.; Dammer, E.B.; Diner, I.; Yi, H.; Seyfried, N.T.; Gearing, M.; Glass, J.D.; Montine, T.J.; Levey, A.I.; Lah, J.J. Aggregates of small nuclear ribonucleic acids (snRNAs) in Alzheimer's disease. Brain Pathol. 2014, 24, 344-351. [CrossRef]

88. Hales, C.M.; Dammer, E.B.; Deng, Q.; Duong, D.M.; Gearing, M.; Troncoso, J.C.; Thambisetty, M.; Lah, J.J.; Shulman, J.M.; Levey, A.I.; et al. Changes in the detergent-insoluble brain proteome linked to amyloid and tau in Alzheimer's Disease progression. Proteomics 2016, 16, 3042-3053. [CrossRef]

89. Cheng, Z.; Shang, Y.; Gao, S.; Zhang, T. Overexpression of U1 snRNA induces decrease of U1 spliceosome function associated with Alzheimer's disease. J. Neurogenet. 2017, 31, 337-343. [CrossRef] 
90. Cheng, Z.; Du, Z.; Zhai, B.; Yang, Z.; Zhang, T. U1 small nuclear RNA overexpression implicates autophagic-lysosomal system associated with AD. Neurosci. Res. 2018, 136, 48-55. [CrossRef]

91. Ohe, K.; Mayeda, A. HMGA1a trapping of U1 snRNP at an authentic 5' splice site induces aberrant exon skipping in sporadic Alzheimer's disease. Mol. Cell. Biol. 2010, 30, 2220-2228. [CrossRef] [PubMed]

92. Liu, X.Y.; Li, H.L.; Su, J.B.; Ding, F.H.; Zhao, J.J.; Chai, F.; Li, Y.X.; Cui, S.C.; Sun, F.Y.; Wu, Z.Y.; et al. Regulation of RAGE splicing by hnRNP A1 and Tra2beta-1 and its potential role in AD pathogenesis. J. Neurochem. 2015, 133, 187-198. [CrossRef] [PubMed]

93. Nuzzo, D.; Inguglia, L.; Walters, J.; Picone, P.; Di Carlo, M. A Shotgun Proteomics Approach Reveals a New Toxic Role for Alzheimer's Disease Abeta Peptide: Spliceosome Impairment. J. Proteome Res. 2017, 16, 1526-1541. [CrossRef] [PubMed]

94. Bu, X.L.; Yao, X.Q.; Jiao, S.S.; Zeng, F.; Liu, Y.H.; Xiang, Y.; Liang, C.R.; Wang, Q.H.; Wang, X.; Cao, H.Y.; et al. A study on the association between infectious burden and Alzheimer's disease. Eur. J. Neurol. 2015, 22, 1519-1525. [CrossRef] [PubMed]

95. Qin, Q.; Li, Y. Herpesviral infections and antimicrobial protection for Alzheimer's disease: Implications for prevention and treatment. J. Med. Virol. 2019, 91, 1368-1377. [CrossRef] [PubMed]

96. Sochocka, M.; Zwolinska, K.; Leszek, J. The Infectious Etiology of Alzheimer's Disease. Curr. Neuropharmacol. 2017, 15, 996-1009. [CrossRef]

97. Licastro, F.; Carbone, I.; Raschi, E.; Porcellini, E. The 21st century epidemic: Infections as inductors of neuro-degeneration associated with Alzheimer's Disease. Immun. Ageing 2014, 11, 22. [CrossRef]

98. Hemling, N.; Roytta, M.; Rinne, J.; Pollanen, P.; Broberg, E.; Tapio, V.; Vahlberg, T.; Hukkanen, V. Herpesviruses in brains in Alzheimer's and Parkinson's diseases. Ann. Neurol. 2003, 54, 267-271. [CrossRef]

99. Malaguarnera, M.; Bella, R.; Alagona, G.; Ferri, R.; Carnemolla, A.; Pennisi, G. Helicobacter pylori and Alzheimer's disease: A possible link. Eur. J. Intern. Med. 2004, 15, 381-386. [CrossRef]

100. Bibi, F.; Yasir, M.; Sohrab, S.S.; Azhar, E.I.; Al-Qahtani, M.H.; Abuzenadah, A.M.; Kamal, M.A.; Naseer, M.I. Link between chronic bacterial inflammation and Alzheimer disease. CNS Neurol. Disord. Drug Targets 2014, 13, 1140-1147. [CrossRef]

101. Miklossy, J. Historic evidence to support a causal relationship between spirochetal infections and Alzheimer's disease. Front. Aging Neurosci. 2015, 7, 46. [CrossRef] [PubMed]

102. Kountouras, J.; Boziki, M.; Gavalas, E.; Zavos, C.; Deretzi, G.; Grigoriadis, N.; Tsolaki, M.; Chatzopoulos, D.; Katsinelos, P.; Tzilves, D.; et al. Increased cerebrospinal fluid Helicobacter pylori antibody in Alzheimer's disease. Int. J. Neurosci. 2009, 119, 765-777. [CrossRef] [PubMed]

103. Wang, X.L.; Zeng, J.; Yang, Y.; Xiong, Y.; Zhang, Z.H.; Qiu, M.; Yan, X.; Sun, X.Y.; Tuo, Q.Z.; Liu, R.; et al. Helicobacter pylori filtrate induces Alzheimer-like tau hyperphosphorylation by activating glycogen synthase kinase-3beta. J. Alzheimers Dis. 2015, 43, 153-165. [CrossRef] [PubMed]

104. Gella, A.; Durany, N. Oxidative stress in Alzheimer disease. Cell Adhes. Migr. 2009, 3, 88-93. [CrossRef] [PubMed]

105. Lillenes, M.S.; Rabano, A.; Stoen, M.; Riaz, T.; Misaghian, D.; Mollersen, L.; Esbensen, Y.; Gunther, C.C.; Selnes, P.; Stenset, V.T.; et al. Altered DNA base excision repair profile in brain tissue and blood in Alzheimer's disease. Mol. Brain 2016, 9, 61. [CrossRef]

106. Chen, Z.S.; Chan, H.Y.E. Transcriptional dysregulation in neurodegenerative diseases: Who tipped the balance of Yin Yang 1 in the brain? Neural Regen. Res. 2019, 14, 1148-1151. [CrossRef]

107. Li, M.D.; Burns, T.C.; Morgan, A.A.; Khatri, P. Integrated multi-cohort transcriptional meta-analysis of neurodegenerative diseases. Acta Neuropathol. Commun. 2014, 2, 93. [CrossRef]

108. Huang, N.Q.; Jin, H.; Zhou, S.Y.; Shi, J.S.; Jin, F. TLR4 is a link between diabetes and Alzheimer's disease. Behav. Brain Res. 2017, 316, 234-244. [CrossRef]

109. Aubry, S.; Shin, W.; Crary, J.F.; Lefort, R.; Qureshi, Y.H.; Lefebvre, C.; Califano, A.; Shelanski, M.L. Assembly and interrogation of Alzheimer's disease genetic networks reveal novel regulators of progression. PLoS ONE 2015, 10, e0120352. [CrossRef]

110. Nowak, K.; Lange-Dohna, C.; Zeitschel, U.; Gunther, A.; Luscher, B.; Robitzki, A.; Perez-Polo, R.; Rossner, S. The transcription factor Yin Yang 1 is an activator of BACE1 expression. J. Neurochem. 2006, 96, 1696-1707. [CrossRef]

111. Rossner, S.; Sastre, M.; Bourne, K.; Lichtenthaler, S.F. Transcriptional and translational regulation of BACE1 expression-implications for Alzheimer's disease. Prog. Neurobiol. 2006, 79, 95-111. [CrossRef] [PubMed] 
112. Lahiri, D.K.; Ge, Y.W.; Rogers, J.T.; Sambamurti, K.; Greig, N.H.; Maloney, B. Taking down the unindicted co-conspirators of amyloid beta-peptide-mediated neuronal death: Shared gene regulation of BACE1 and APP genes interacting with CREB, Fe65 and YY1 transcription factors. Curr. Alzheimer Res. 2006, 3, 475-483. [CrossRef] [PubMed]

113. Lanke, V.; Moolamalla, S.T.R.; Roy, D.; Vinod, P.K. Integrative Analysis of Hippocampus Gene Expression Profiles Identifies Network Alterations in Aging and Alzheimer's Disease. Front. Aging Neurosci. 2018, 10, 153. [CrossRef] [PubMed]

114. Ge, Y.W.; Ghosh, C.; Song, W.; Maloney, B.; Lahiri, D.K. Mechanism of promoter activity of the beta-amyloid precursor protein gene in different cell lines: Identification of a specific $30 \mathrm{bp}$ fragment in the proximal promoter region. J. Neurochem. 2004, 90, 1432-1444. [CrossRef] [PubMed]

115. Mastrocola, R.; Guglielmotto, M.; Medana, C.; Catalano, M.G.; Cutrupi, S.; Borghi, R.; Tamagno, E.; Boccuzzi, G.; Aragno, M. Dysregulation of SREBP2 induces BACE1 expression. Neurobiol. Dis. 2011, 44, 116-124. [CrossRef] [PubMed]

116. Barbero-Camps, E.; Fernandez, A.; Martinez, L.; Fernandez-Checa, J.C.; Colell, A. APP/PS1 mice overexpressing SREBP-2 exhibit combined Abeta accumulation and tau pathology underlying Alzheimer's disease. Hum. Mol. Genet. 2013, 22, 3460-3476. [CrossRef]

117. Picard, C.; Julien, C.; Frappier, J.; Miron, J.; Theroux, L.; Dea, D.; Breitner, J.C.S.; Poirier, J. Alterations in cholesterol metabolism-related genes in sporadic Alzheimer's disease. Neurobiol. Aging 2018,66, 180.e181-180.e189. [CrossRef]

118. Zhang, J.; Shu, Y.; Qu, Y.; Zhang, L.; Chu, T.; Zheng, Y.; Zhao, H. C-myb Plays an Essential Role in the Protective Function of IGF-1 on Cytotoxicity Induced by Abeta25-35 via the PI3K/Akt Pathway. J. Mol. Neurosci. 2017, 63, 412-418. [CrossRef]

119. Gonzalez, P.; Alvarez, V.; Menendez, M.; Lahoz, C.H.; Martinez, C.; Corao, A.I.; Calatayud, M.T.; Pena, J.; Garcia-Castro, M.; Coto, E. Myocyte enhancing factor-2A in Alzheimer's disease: Genetic analysis and association with MEF2A-polymorphisms. Neurosci. Lett. 2007, 411, 47-51. [CrossRef]

120. McKeever, P.M.; Schneider, R.; Taghdiri, F.; Weichert, A.; Multani, N.; Brown, R.A.; Boxer, A.L.; Karydas, A.; Miller, B.; Robertson, J.; et al. MicroRNA Expression Levels Are Altered in the Cerebrospinal Fluid of Patients with Young-Onset Alzheimer's Disease. Mol. Neurobiol. 2018, 55, 8826-8841. [CrossRef]

121. Herrera-Espejo, S.; Santos-Zorrozua, B.; Alvarez-Gonzalez, P.; Lopez-Lopez, E.; Garcia-Orad, A. A Systematic Review of MicroRNA Expression as Biomarker of Late-Onset Alzheimer's Disease. Mol. Neurobiol. 2019. [CrossRef] [PubMed]

122. Siedlecki-Wullich, D.; Catala-Solsona, J.; Fabregas, C.; Hernandez, I.; Clarimon, J.; Lleo, A.; Boada, M.; Saura, C.A.; Rodriguez-Alvarez, J.; Minano-Molina, A.J. Altered microRNAs related to synaptic function as potential plasma biomarkers for Alzheimer's disease. Alzheimers Res. Ther. 2019, 11, 46. [CrossRef] [PubMed]

123. Dursun, E.; Candas, E.; Yilmazer, S.; Gezen-Ak, D. Amyloid Beta 1-42 Alters the Expression of miRNAs in Cortical Neurons. J. Mol. Neurosci. 2019, 67, 181-192. [CrossRef] [PubMed]

124. Yilmaz, S.G.; Erdal, M.E.; Ozge, A.A.; Sungur, M.A. Can Peripheral MicroRNA Expression Data Serve as Epigenomic (Upstream) Biomarkers of Alzheimer's Disease? Omics J. Integr. Biol. 2016, 20, 456-461. [CrossRef] [PubMed]

125. Satoh, J.; Kino, Y.; Niida, S. MicroRNA-Seq Data Analysis Pipeline to Identify Blood Biomarkers for Alzheimer's Disease from Public Data. Biomark Insights 2015, 10, 21-31. [CrossRef] [PubMed]

126. Hebert, S.S.; Horre, K.; Nicolai, L.; Bergmans, B.; Papadopoulou, A.S.; Delacourte, A.; De Strooper, B. MicroRNA regulation of Alzheimer's Amyloid precursor protein expression. Neurobiol. Dis. 2009, 33, 422-428. [CrossRef]

127. Kume, K.; Iwama, H.; Deguchi, K.; Ikeda, K.; Takata, T.; Kokudo, Y.; Kamada, M.; Fujikawa, K.; Hirose, K.; Masugata, H.; et al. Serum microRNA expression profiling in patients with multiple system atrophy. Mol. Med. Rep. 2018, 17, 852-860. [CrossRef]

128. Bofill-De Ros, X.; Santos, M.; Vila-Casadesus, M.; Villanueva, E.; Andreu, N.; Dierssen, M.; Fillat, C. Genome-wide miR-155 and miR-802 target gene identification in the hippocampus of Ts65Dn Down syndrome mouse model by miRNA sponges. BMC Genom. 2015, 16, 907. [CrossRef]

129. Keck-Wherley, J.; Grover, D.; Bhattacharyya, S.; Xu, X.; Holman, D.; Lombardini, E.D.; Verma, R.; Biswas, R.; Galdzicki, Z. Abnormal microRNA expression in Ts65Dn hippocampus and whole blood: Contributions to Down syndrome phenotypes. Dev. Neurosci. 2011, 33, 451-467. [CrossRef]

130. Nuovo, G.; Tili, E.; Awad, H.; Michaille, J.J. Roles of miR-155 microRNA in dementia associated with Down's syndrome. Med. Sci. 2018, 34, 922-924. [CrossRef] 
131. Tili, E.; Mezache, L.; Michaille, J.J.; Amann, V.; Williams, J.; Vandiver, P.; Quinonez, M.; Fadda, P.; Mikhail, A.; Nuovo, G. microRNA 155 up regulation in the CNS is strongly correlated to Down's syndrome dementia. Ann. Diagn. Pathol. 2018, 34, 103-109. [CrossRef] [PubMed]

132. Liu, D.; Zhao, D.; Zhao, Y.; Wang, Y.; Wen, C. Inhibition of microRNA-155 Alleviates Cognitive Impairment in Alzheimer's Disease and Involvement of Neuroinflammation. Curr. Alzheimer Res. 2019, 16, 473-482. [CrossRef] [PubMed]

133. Song, J.; Lee, J.E. miR-155 is involved in Alzheimer's disease by regulating T lymphocyte function. Front. Aging Neurosci. 2015, 7, 61. [CrossRef] [PubMed]

134. Guedes, J.R.; Custodia, C.M.; Silva, R.J.; de Almeida, L.P.; Pedroso de Lima, M.C.; Cardoso, A.L. Early miR-155 upregulation contributes to neuroinflammation in Alzheimer's disease triple transgenic mouse model. Hum. Mol. Genet. 2014, 23, 6286-6301. [CrossRef] [PubMed]

135. Sierksma, A.; Lu, A.; Salta, E.; Vanden Eynden, E.; Callaerts-Vegh, Z.; D’Hooge, R.; Blum, D.; Buee, L.; Fiers, M.; De Strooper, B. Deregulation of neuronal miRNAs induced by amyloid-beta or TAU pathology. Mol. Neurodegener. 2018, 13, 54. [CrossRef] [PubMed]

136. Chen, J.; Qi, Y.; Liu, C.F.; Lu, J.M.; Shi, J.; Shi, Y. MicroRNA expression data analysis to identify key miRNAs associated with Alzheimer's disease. J. Gene Med. 2018, 20, e3014. [CrossRef]

137. Caggiu, E.; Paulus, K.; Mameli, G.; Arru, G.; Sechi, G.P.; Sechi, L.A. Differential expression of miRNA 155 and miRNA 146a in Parkinson's disease patients. eNeurologicalSci 2018, 13, 1-4. [CrossRef]

138. Cheng, X.R.; Cui, X.L.; Zheng, Y.; Zhang, G.R.; Li, P.; Huang, H.; Zhao, Y.Y.; Bo, X.C.; Wang, S.Q.; Zhou, W.X.; et al. Nodes and biological processes identified on the basis of network analysis in the brain of the senescence accelerated mice as an Alzheimer's disease animal model. Front. Aging Neurosci. 2013, 5, 65. [CrossRef]

139. Bennett, D.A.; Schneider, J.A.; Arvanitakis, Z.; Kelly, J.F.; Aggarwal, N.T.; Shah, R.C.; Wilson, R.S. Neuropathology of older persons without cognitive impairment from two community-based studies. Neurology 2006, 66, 1837-1844. [CrossRef]

140. Jendroska, K.; Poewe, W.; Daniel, S.E.; Pluess, J.; Iwerssen-Schmidt, H.; Paulsen, J.; Barthel, S.; Schelosky, L.; Cervos-Navarro, J.; DeArmond, S.J. Ischemic stress induces deposition of amyloid beta immunoreactivity in human brain. Acta Neuropathol. 1995, 90, 461-466. [CrossRef]

141. Launer, L.J.; Ross, G.W.; Petrovitch, H.; Masaki, K.; Foley, D.; White, L.R.; Havlik, R.J. Midlife blood pressure and dementia: The Honolulu-Asia aging study. Neurobiol. Aging 2000, 21, 49-55. [CrossRef]

142. Leibson, C.L.; Rocca, W.A.; Hanson, V.A.; Cha, R.; Kokmen, E.; O’Brien, P.C.; Palumbo, P.J. Risk of dementia among persons with diabetes mellitus: A population-based cohort study. Am. J. Epidemiol. 1997, 145, 301-308. [CrossRef] [PubMed]

143. Craft, S.; Dagogo-Jack, S.E.; Wiethop, B.V.; Murphy, C.; Nevins, R.T.; Fleischman, S.; Rice, V.; Newcomer, J.W.; Cryer, P.E. Effects of hyperglycemia on memory and hormone levels in dementia of the Alzheimer type: A longitudinal study. Behav. Neurosci. 1993, 107, 926-940. [CrossRef] [PubMed]

144. Meneilly, G.S.; Hill, A. Alterations in glucose metabolism in patients with Alzheimer's disease. J. Am. Geriatr. Soc. 1993, 41, 710-714. [CrossRef] [PubMed]

145. Ott, A.; Stolk, R.P.; Hofman, A.; van Harskamp, F.; Grobbee, D.E.; Breteler, M.M. Association of diabetes mellitus and dementia: The Rotterdam Study. Diabetologia 1996, 39, 1392-1397. [CrossRef]

146. Tan, Z.S.; Seshadri, S.; Beiser, A.; Zhang, Y.; Felson, D.; Hannan, M.T.; Au, R.; Wolf, P.A.; Kiel, D.P. Bone mineral density and the risk of Alzheimer disease. Arch. Neurol. 2005, 62, 107-111. [CrossRef]

147. Kwok, M.K.; Lin, S.L.; Schooling, C.M. Re-thinking Alzheimer's disease therapeutic targets using gene-based tests. EBioMedicine 2018, 37, 461-470. [CrossRef]

148. Kupershmidt, I.; Su, Q.J.; Grewal, A.; Sundaresh, S.; Halperin, I.; Flynn, J.; Shekar, M.; Wang, H.; Park, J.; Cui, W.; et al. Ontology-based meta-analysis of global collections of high-throughput public data. PLoS ONE 2010, 5, e13066. [CrossRef]

149. Lex, A.; Gehlenborg, N.; Strobelt, H.; Vuillemot, R.; Pfister, H. UpSet: Visualization of Intersecting Sets. IEEE Trans. Vis. Comput Graph. 2014, 20, 1983-1992. [CrossRef]

150. Xia, J.; Gill, E.E.; Hancock, R.E. NetworkAnalyst for statistical, visual and network-based meta-analysis of gene expression data. Nat. Protoc. 2015, 10, 823-844. [CrossRef]

151. Zhou, G.; Soufan, O.; Ewald, J.; Hancock, R.E.W.; Basu, N.; Xia, J. NetworkAnalyst 3.0: A visual analytics platform for comprehensive gene expression profiling and meta-analysis. Nucleic Acids Res. 2019, 47, W234-W241. [CrossRef] [PubMed] 
152. Kanehisa, M.; Goto, S. KEGG: Kyoto encyclopedia of genes and genomes. Nucleic Acids Res. 2000, 28, 27-30. [CrossRef] [PubMed]

153. ENCODE_Project_Consortium. A user's guide to the encyclopedia of DNA elements (ENCODE). PLoS Biol. 2011, 9, e1001046. [CrossRef] [PubMed]

154. Lachmann, A.; Xu, H.; Krishnan, J.; Berger, S.I.; Mazloom, A.R.; Ma'ayan, A. ChEA: Transcription factor regulation inferred from integrating genome-wide ChIP-X experiments. Bioinformatics 2010, 26, 2438-2444. [CrossRef]

155. Khan, A.; Fornes, O.; Stigliani, A.; Gheorghe, M.; Castro-Mondragon, J.A.; van der Lee, R.; Bessy, A.; Cheneby, J.; Kulkarni, S.R.; Tan, G.; et al. JASPAR 2018: Update of the open-access database of transcription factor binding profiles and its web framework. Nucleic Acids Res. 2018, 46, D260-D266. [CrossRef]

156. Karagkouni, D.; Paraskevopoulou, M.D.; Chatzopoulos, S.; Vlachos, I.S.; Tastsoglou, S.; Kanellos, I.; Papadimitriou, D.; Kavakiotis, I.; Maniou, S.; Skoufos, G.; et al. DIANA-TarBase v8: A decade-long collection of experimentally supported miRNA-gene interactions. Nucleic Acids Res. 2018, 46, D239-D245. [CrossRef]

157. Sethupathy, P.; Corda, B.; Hatzigeorgiou, A.G. TarBase: A comprehensive database of experimentally supported animal microRNA targets. RNA 2006, 12, 192-197. [CrossRef]

158. Chou, C.H.; Shrestha, S.; Yang, C.D.; Chang, N.W.; Lin, Y.L.; Liao, K.W.; Huang, W.C.; Sun, T.H.; Tu, S.J.; Lee, W.H.; et al. miRTarBase update 2018: A resource for experimentally validated microRNA-target interactions. Nucleic Acids Res. 2018, 46, D296-D302. [CrossRef]

159. Pinero, J.; Bravo, A.; Queralt-Rosinach, N.; Gutierrez-Sacristan, A.; Deu-Pons, J.; Centeno, E.; Garcia-Garcia, J.; Sanz, F.; Furlong, L.I. DisGeNET: A comprehensive platform integrating information on human disease-associated genes and variants. Nucleic Acids Res. 2017, 45, D833-D839. [CrossRef]

(C) 2019 by the authors. Licensee MDPI, Basel, Switzerland. This article is an open access article distributed under the terms and conditions of the Creative Commons Attribution (CC BY) license (http://creativecommons.org/licenses/by/4.0/). 